\title{
Risk contagion in the cross-border banking network: Some new
}

\section{evidence}

\section{Bing Chen ${ }^{1}, \mathrm{Li} \mathrm{Li}^{2}$, Fei Peng ${ }^{3}$, Ruhul Salim ${ }^{4 *}$}

${ }^{1}$ School of Finance, Shanghai Lixin University of Accounting and Finance, No.995 Shangchuan Road, Shanghai, 201209, China.

$\underline{2}$ School of Business Information, Shanghai University of International Business and Economics, No.1900 Wenxiang Road, Songjiang District, Shanghai, 201620, China.

${ }^{3}$ Department of Economics, Shanghai Lixin University of Accounting and Finance, No.995 Shangchuan Road, Shanghai, 201209, China. Email: pengfei@lixin.edu.cn ${ }^{4}$ School of Economics, Finance and Property, Curtin University, WA 6102, Australia.

\section{Acknowledgements}

Financial aids from the China National Ministry of Education Humanities and Social Sciences Research Youth Fund Project (12YJC790004), the Shanghai Education Commission Research and Innovation Key Project (12ZS184) and the Shanghai Young Eastern Scholar (QD2015049) are acknowledged. The data used here are with the permission of the Bank for International Settlement (BIS). Neither the original collectors of the data nor distributors bear any responsibility for the analyses or interpretations presented here. We are also grateful to the anonymous reviewer for providing helpful comments which materially improved quality and presentation this article. However, all remaining errors are our own. 
Corresponding author: Corresponding author: Professor Ruhul Salim, School of Economics, Finance \& Property, Curtin Business School, Curtin University, Perth, WA 6845, Australia. E-mail: Ruhul.Salim@cbs.curtin.edu.au

\title{
Risk contagion in the cross-border banking network: Some new evidence
}

\begin{abstract}
This paper applies consolidated banking statistics data from the Bank for International Settlement (BIS) to simulate risk contagion in a cross-border banking system with shocks of credit and liquidity. Simulation results from balance sheet network analysis show that the banking systems of the US and UK are the most systemically important systems under the credit shocks in June 2008. Moreover, banking system 's counter-shocks ability is directly related to its size and concentration of foreign claims. The banking systems of German and French are the most systemically important systems under the liquidity shocks. Some banking systems depend heavily on German and French banking systems for financing and are vulnerable to liquidity shocks. Risk transfer has influence on risk contagion in the cross-border banking system. After the subprime crisis, cross-border risk contagion has declined because of deleveraging foreign claims. Raising the capital level of the banking system or intervention in the interbank market to enhance the liquidity of the market under pressure scenarios can reduce the contagion effect of credit or liquidity shocks.
\end{abstract}

Key Words: Cross-border Banking Network; Banking System; Credit Shock; Liquidity Shock; Contagion

JEL Classification: G01; D85; G21; F37; G28 


\section{Risk contagion in the cross-border banking network: Some new evidence}

\section{Introduction}

The debts of cross-border banks have increased rapidly since the 1980s with the impetus of financial liberalization and globalization. According to the statistics of Bank for International Settlements (BIS, 2017), each of 40 countries (regions) has had more than $\$ 100$ billion in debt to foreign banking systems by the end of December 2017. Among them, the United States, Britain, Germany, the Cayman Islands, China and France owe more than $\$ 10$ trillion to the foreign banking system ${ }^{1}$, reflecting the close ties between the banking system and the global economy.

BIS data show that there is an increasing trend of foreign claims of the major developed countries from 2000 to the outbreak of the subprime crisis (Figure 1). It also reveals that European countries' banking systems began to fall after their foreign claims reached its peak immediately before the 2008 subprime crisis. Among them, the banking systems of Germany, France, Belgium, Switzerland, Denmark, Ireland, and the Netherlands have seen a significant decline in foreign claims, in particular, the foreign claims of Belgian banking system declined from \$1632.7 billion in June 2008 to $\$ 220$ billion in December 2017, which may be related to the deleveraging of the European banking system.

\section{(Figures 1 is around here)}

1 Data sources: BIS 
The rapid growth of the foreign claims of banking system has formed an increasingly complex cross-border banking network in which the risk sharing of the banking system and cross-border risk contagion might happen at the same time (Minoiu \& Reyes, 2013; Allen \& Gale, 2000). Hence, in this context, it is of great practical and academic significance to investigate the risk contagion in the cross-border banking systems. Thus, the aim of this study is to simulate risk contagion in a cross-border banking system with shocks of credit and liquidity by using consolidated banking statistics data from the Bank for International Settlement (BIS).

In the subprime crisis, the impact of Lehman Brothers' bankruptcy in September 2008 spread rapidly in the global financial network, indicating that the interdependence between the banking systems amplified the response to the impact and aggravated the contagion of financial risks (Panageas, 2010; Acharya et al., 2011; Aiyar, 2012; Acharya et al., 2015).

After the subprime crisis, the contagion and systemic risks caused by interconnection between banking systems have attracted great attention (Acharya et al., 2012; Liang, 2013; Allen and Carletti, 2013; Elliott et al., 2014; Acemoglu et al., 2015; Glasserman and Young, 2015; Georg, 2013). The network analysis can be used through simulating shock to reveal the contagion effect of cross-border risk to the banking systems of a number of countries (Espinosa-Vega \& Solé 2010). Thus, the significance of our study is to understand the contagion mechanism of financial risk more intuitively by simulating the transmission of different types of shocks across the cross-border banking network. This method provides a tool for monitoring the pressure scenarios of the banking system for regulators, it can be used to assess the risk contagion in a country's banking system to grasp the dynamic changes of financial contagion and to play a role in early warning.

The remainder of this paper is structured as follows. Section 2 reviews the relevant literature, followed by the discussion on simulation methods and algorithms in Section 3. Discussion on data sources is given in Section 4. Section 5 analyses the construction and characteristic of cross-border banking network, while Section 6 
presents empirical results. Finally, the summary of findings and policy implications are given in Section 7.

\section{Literature review}

There are three types of literature related to the risk contagion of interbank linkages. The first kind of literature is based on the data of interbank bilateral lending in a country's banking system to simulate the contagion effect, there are a number of such studies $^{2}$. This kind of research mainly uses the maximum entropy method to estimate the bilateral lending matrix, and then uses the balance sheet network analysis method to simulate the contagion effect, the simulation method is similar to that in this article.

The second strand of literature simulates the contagion effect of cross-border risk by using the Locational Banking Statistics data of BIS. Tonzer (2015), Garratt et al. (2014), Kubelec \& Sa (2012), Chinazzi et al. (2012), Minoiu \& Reyes (2013) are typical representative. Locational banking statistics count the claims data of a country's bank (including domestic and foreign banks) against another country based on the principle of residence, it includes the trading positions between the branches of the same bank group (in two countries). This paper is based on BIS's Consolidated Banking Statistics data, distributes of foreign banking institutions to the country of headquarters for statistics, and excludes the trading positions between the branches of the same bank group in different countries. Thus, it can capture the impact of external shocks on a country's banking system.

The third strand of researches has the highest correlation with this paper, it simulates contagion effect of cross-border risk by using BIS's Consolidated Banking Statistics data. Degryse et al. (2010) used BIS's Immediate Borrower Basis (IBB) ${ }^{3}$ data of 17 countries' banking systems for the first time to simulate the time varying of

\footnotetext{
${ }^{2}$ For example, Sheldon \& Maurer (1998) and Müller (2006) for Switzerland, Blavarg \& Nimander (2002) and Frisell et al. (2007) for Sweden, Furfine (2003) for the United States, Boss et al. (2004) and Elsinger et al. (2006a) for Austria, Upper \& Worms (2004) and Memmel \& Stein (2008) for Germany, Wells (2004) and Elsinger et al. (2006b) for Britain, Amundsen \& Arnt (2005) for Denmark, Lublóy (2005) for Hungary, Van Lelyveld \& Liedorp (2006) for Netherland, Mistrulli (2007) for Italy, Degryse \& Nguyen (2007) for Belgian , Guerrero-Gómez \& Lopez-Gallo (2004) for Mexico, Toivanen (2009) for Finland, Hausenblas et al. (2015) for Czech.

3 Detailed explanations of IBB data are given in part IV.
} 
cross-border risk contagion for the period of 1999-2006. The simulation results show that the risk and speed of contagion caused by cross-border risk exposure have increased during 1999-2006. These authors distinguished three systemic shocks (a country's banking system defaults on foreign debt), under the condition of default loss rate $(\lambda) 100 \%$, if the US, UK and German banking systems default on foreign debt by $25 \%, 35 \%, 60 \%$, the loss proportion of the entire banking system will be $95 \%, 45 \%$, and $50 \%$, respectively. The shock on Eastern Europe, Turkey and Russia have affected most countries since 2006. Contagion is more likely to occur among geographically similar countries i.e., contagion is regional, not global. The US is the only immune country to cross-border contagion. Degryse et al. (2010) only considered the credit shock and did not take into account the effect of liquidity shock. Paltalidis et al. (2015) used BIS cross-border exposure data to simulate the systemic risk contagion of the euro zone banking network, the results show that contagion through sovereign credit risk channel is the most important source of systemic risk. Moreover, the southern European banking system is more vulnerable to bank failures caused by financial contagion than the northern European banking system.

Cross-border risk contagion has attracted considerable attention from some scholars after the subprime crisis, including IMF and BIS researchers. Espinosa-Vega \& Solé (2010) simulated cross-border contagion effect in different types of shock (e.g. credit shock, credit shock plus liquidity shock) by using IBB data of 18 countries' banking systems from BIS, and examined the change of contagion effect caused by credit risk transfer using Ultimate Risk Basis $(\mathrm{URB})^{4}$ data. Simulation analysis shows that the US and British banking system are the most important node in the network. On the contrary, the banking system of Belgium, Sweden and Switzerland are the most vulnerable node. The effect of contagion is magnified after credit shock plus liquidity shock, in particular, the simulation results of the French, German, Italy and Spanish banking systems are distinctly different. Chan-Lau (2010) applies the same approach to analyze the contagion effect consisting of 20 countries' banking

\footnotetext{
${ }^{4}$ Detailed explanations of URB data are given in part IV.
} 
system and of Chilean banking network. The same approach is also used by Chan-Lau et al. (2009) to analyze cross-border risk contagion problems in the global financial stability report of IMF in April 2009. The advantages of the approach are: it can clearly show the path of contagion, quantifies potential capital loss, identifies important and fragile financial institution or banking system in the network. However, the drawback of this approach is that it requires risk exposure data from different financial institutions or banking systems. In addition, static simulation cannot reveal the dynamic change process of risk.

This paper contributes to current literature in following ways. Firstly, in terms of data sources, Degryse et al. (2010) used only common stock from Bankscope dataset as bank capital, there are certain deviations between common stock and bank capital. ${ }^{5}$ Espinosa-Vega \& Solé (2010) also used capital data of banking system from Bankscope but selected capital data of the commercial bank and investment bank only, which underestimated capital level of the total banking system. We improve the data quality by using the most recently available data from the BIS for all kinds of capital in the national (regional) banking system. Secondly, in terms of sample selection, Degryse et al. (2010), Espinosa-Vega \& Solé (2010) included 17 and 18 countries' banking systems respectively, and all of them included Finland's banking system. Degryse et al. (2010) did not include Australian and Greek banking systems, but it included Danish banking system. The sample of this paper selects 18 banking systems, excluding Finland and Danish banking systems, but it includes Turkey's banking systems. According to the instructions on Consolidated Banking Statistics of BIS, Danish banking system only releases IBB data and does not release URB data. Hence, it cannot be investigated the impact on risk transfer to contagion effect. Again, the IBB and URB data of Finland banking system did not decompose counterparties from the first quarter of 2004 to the first quarter of 2010, that is to say, the national data of

\footnotetext{
5 In the Basel agreement II, bank capital includes core capital and subsidiary capital. And, core capital includes the permanent shareholders' equity (that is, common stock and permanent non-cumulative preferred stock), and open reserve. Obviously, the common stock used in Degryse et al. (2010) is only part of the core capital of banks and cannot represent for all kinds of capital.
} 
its foreign claims are not available. Thirdly, unlike Espinosa-Vega \& Solé (2010), when the contagion effects of credit and liquidity shocks are simulated in this paper, the values of default loss rate $(\lambda)$, the ratio of non-extended interbank debt $(\rho)$ and asset discount rate $(\delta)$ are not fixed values, but continuous values, so as to show more clearly the contagion effects and characteristics of different banking systems under different parameter levels. Fourthly, Degryse et al. (2010) simulated the cross-border risk contagion situation before 2006. Espinosa-Vega \& Solé (2010) simulated the cross-border risk contagion situation at the end of 2007. While this paper simulated the cross-border risk contagion effect in the subprime crisis based on the time point before the collapse of Lehman Brothers in June 2008, and examined the change trend of cross-border risk contagion after the subprime crisis. Finally, under the simulation of credit shocks, this paper identifies the systemic importance of the US and British banking systems. Under the simulation of liquidity shocks, it identifies the systemic importance of German and French banking systems. The reason for this difference lies in the different positions of the first two systems and the last two systems in the cross-border banking network. The foreign debts of the US and British banking systems are much larger than that of foreign claims, once the two banking systems default on the debt, the other banking systems suffer a serious credit shock. On the contrary, the claims of German and French banking systems is larger than that of foreign debts, once the two banking systems do not roll over debts and trigger asset fire-sale, other banking systems that rely heavily on them for financing are severely affected by liquidity shocks. The location of the banking system in the banking network is an important variable affecting the contagion effect.

\section{Methods and algorithms for shock simulation}

\subsection{Simulation methods}

Considering a network consisting of $N$ banks. The identities of the bank's balance sheet is as follows:

$$
\sum_{j} x_{j \leftarrow i}+a_{i}=k_{i}+b_{i}+d_{i}+\sum_{j} x_{i \leftarrow j}
$$


$x_{j \leftarrow i}$ represents bank $i$ loan to bank $j, a_{i}$ represents the other assets of bank $i, k_{i}$ represents the capital of bank $i, b_{i}$ are long-term and short-term borrowing (excluding interbank borrowing), $d_{i}$ means deposit, $x_{i \leftarrow j}$ represents bank $i$ 's borrowing from bank $j$.

\subsubsection{The transmission of credit shock}

First, we simulate the default of each bank in the network of $N$ banks, on the assumption of different rate of default loss $(\lambda)$, supposed the capital of bank $i$ first absorbs loss, then we tracks the order of default. It is assumed that bank $i$ 's credit loss $\lambda x_{h \leftarrow i}$ is caused by bank $h$ default, the identities of bank $i$ 's balance sheet after credit shock is changed into:

$$
a_{i}+\sum_{j} x_{j \leftarrow i}-\lambda x_{h \leftarrow i}=\left(k_{i}-\lambda x_{h \leftarrow i}\right)+b_{i}+d_{i}+\sum_{j} x_{i \leftarrow j}
$$

If the capital of bank $i$ 's is not enough to absorb the loss, then bank $i$ will go bankrupt.

\subsubsection{The transmission of liquidity shock}

Suppose that bank $i$ do not fully roll over interbank financing due to counterparty default, bank $i$ have no other sources of financing (excluding the possibility of getting new capital), then bank $i$ will be forced to sell some assets at a discount (the price of the market is less than the book value) in order to maintain the identities constant of the balance sheet. And assume that the loss caused by the financing gap is absorbed by bank capital. It is assumed that bank $i$ can only extend $(1-\rho)$ portion of the financing from the bank $h$. It triggers bank $i$ 's assets to be sold at discount rate $\delta(\delta>0)$. So the bank needs to sell $(1+\delta) \rho x_{i \leftarrow h}$ assets of the book value to make up the financing gap $\rho x_{i \leftarrow h}$. The loss $\delta \rho x_{i \leftarrow h}$ caused by the financing gap is absorbed by the capital of bank $i$. The basic identity of balance sheet of bank $i$ after shock is changed into: 


$$
a_{i}+\sum_{j} x_{j \leftarrow i}-(1+\delta) \rho x_{i \leftarrow h}=\left(k_{i}-\delta \rho x_{i \leftarrow h}\right)+b_{i}+d_{i}+\sum_{j} x_{i \leftarrow j}-\rho x_{i \leftarrow h}
$$

The bank $i$ has suffered loss $\delta \rho x_{i \leftarrow h}$ due to financing gap. If the bank $i$ 's capital is not enough to absorb the loss $\left(k_{i}-\delta \rho x_{i \leftarrow h}<0\right)$, then bank $i$ will go bankrupt. Similarly, bank $i$ failure will further cause financing shock to other banks.

\subsection{Simulation algorithms}

Using Matlab software to write network algorithm, $N$ nodes form a banking system, interbank loan compose $N \times N$ matrix, $F_{t}$ represents the bankrupt financial institution, $N F_{t}$ represents non bankrupt financial institutions.

\subsubsection{The simulation of credit shock}

Supposed bank $h$ is bankrupt at the time $t=0$, then the bank will default $\lambda$ part of the debt to other banks. For any bank $i \quad(i \neq h)$, checking whether bank $i$ 's loss $\lambda x_{h \leftarrow i}$ are greater than its capital. If the loss is greater than the capital, bank $i$ will

go bankrupt, that is: $\sum_{h \in F_{t}} \lambda x_{h \leftarrow i} \geq k_{i}$, bank $i$ go bankrupt and $i \in F_{t+1}$. Once $F_{t}=F_{t+1}$, algorithm convergences.

\subsubsection{The simulation of liquidity shock}

The loss at this time is equal to the loss $\delta \rho x_{i \leftarrow h}$ caused by the liquidity shortage. At each stage of the simulation, bank capital is also affected by the fire sale of asset, therefore, the condition of default is: $\sum_{h \in F_{t}} \delta \rho x_{i \leftarrow h} \geq k_{i}$, bank $i$ go bankrupt and $i \in F_{t+1}$. Similarly, once $F_{t}=F_{t+1}$, algorithm convergence.

\section{Data Description}

This paper simulates cross-border banking risk contagion based on BIS's consolidated banking data. There are two forms of bilateral exposure data for cross-border banking system that are counted by the database: Immediate Borrower Basis (IBB) and Ultimate Risk Basis (URB). The two forms of data is to combine the loan data of the overseas branch of the loan bank to the country of the headquarters, but URB form 
also combines the debt data to the final debtor's country based on jurisdiction. Therefore, URB data includes net risk transfer. For example, the Citibank London branch loan to the HSBC Paris branch, it is the US loan to France according to IBB, and according to URB statistics is the US loan to Britain. IBB captures the origin of risk, and URB captures the ultimate source of risk ${ }^{6}$.

Sample banking system selection criteria are as follows. Firstly, consolidated banking statistics (including IBB and URB data) should be continuous and complete without interruption. Secondly, the capital data of banking system in different time points can be obtained. According to these two criteria, the final selected sample banking system include: Austria (AT), Australia (AU), Belgium (BE), Canada (CA), Switzerland (CH), Germany (DE), Spain (ES), France (FR), Greece (GR), Ireland (IE), Italy (IT), Japan (JP), Netherlands (NL), Portugal (PT), Sweden (SE), Turkey (TR), the United Kingdom (UK) and the United States (US), total of 18 countries' banking system.

Capital data of the banking systems come from various sources. Capital data of Canada, Switzerland and Turkey banking system come from respective country's central banks' websites. Capital data of the US, Japan banking system come from WIND database. ${ }^{7}$ And capital data of European countries banking system come from ECB statistical database. Capital data of Australian banking system come from the Australian Prudential Regulation Authority. All banking systems' capital data are converted into the US dollar in accordance with the corresponding time point exchange rate.

\footnotetext{
${ }^{6}$ According to the latest data released in December 2017 of BIS's report, a total of 29 countries (regions) released IBB data, and 24 countries (regions) released URB data. Luxemburg has released IBB data since 1983, Singapore has released IBB and URB data since 2000 and 2005 respectively, but the data of two countries have never appeared in consolidated banking statistics database. As a result, there are 27 economies that actually release IBB data and 23 economies that release URB data. IBB and URB data are obtained from BIS Statistics Warehouse.

7 WIND database is the market leader in China's financial information services industry, which is widely used in related economic and financial research such as Geng and N'Diaye (2012), Chen et al. (2014) and Li et al. (2016).
} 
Time point selection is as follows: this paper takes June 2008 as the benchmark before the collapse of Lehman Brothers ${ }^{8}$, and the time points of June 2007, December 2007, December 2008, June 2009, December 2009, December 2010, December 2011, December 2012, December 2013, December 2014, December 2015, December 2016 and December 2017 were selected. This paper focuses on the characteristics of cross-border risk contagion in the subprime crisis and the change trend after the crisis broke out.

\section{Cross-border banking network}

Different national banking systems are directly connected because of the relationship between claims and debts, thus forming a cross-border banking network. The nodes in the network are the 18 sample banking systems selected in the front. The edges of the network are the connections between banking systems. The network connections provide a path for risk contagion. In order to reflect the structure and characteristics of the network more clearly, the data of claims and debts between cross-border banking systems should be properly processed. Firstly, we only need to examine the degree of financial linkages between banking systems, not the direction of linkages, so we can merge the data of claims and liabilities. Secondly, because the size of financial linkages between different banking systems are very different, such as the US banking system's claims to Britain in June 2008 is 124.7 billion US dollars, while the Portuguese banking system's claims to Turkey in the same period is only 0.07 billion US dollars, so the threshold is set to be 5 billion US dollars for bilateral linkages, this means that there are no financial linkages between the banking systems with claims and liabilities of less than $\$ 5$ billion. Figure 2 depicts the cross-border banking network in June 2008 (in the subprime crisis). The size of nodes in the network is weighted by the data of claims and liabilities of the banking system. The larger the nodes, the larger the data of claims and liabilities of the banking system. The linkages

\footnotetext{
8 According to the data of BIS consolidated banking statistics, the claims and liabilities of cross-border banking systems had an upward trend by June 2008 (increase leverage), while after the collapse of Lehman brothers, there was a downward trend (deleveraging), which may have an important impact on risk contagion of cross-border banking system.
} 
between nodes is weighted according to the data of claims and debts between banking systems. The thicker the linkages between nodes, the larger the data of claims and debts between two banking systems. The size of the banking system (claims and debts data) and the connectivity between the banking systems have an important impact on risk contagion. The arrow points to the creditor country. If there are arrows between the two banking systems pointing to each other, it indicates that they hold each other's claims. If there is only one arrow, it indicates that only one party has claims to the other party.

\section{(Figures 2 is around here)}

Examining the changes in the structure of cross-border banking network, the number of edges of the network rose before the crisis, from 204 in June 2007 to 211 in June 2008. After the subprime crisis, the number of edges of the network declined significantly, from 197 in December 2009 to 182 at the end of 2010, and then remained generally stable. This reflects the deleveraging of the banking system in major developed countries after the global financial crisis. This can also be supported by cross-border banking system claims data, such as the Canadian banking system's foreign claims is large, but mainly concentrated on the claims of the US, less links with other banking systems. After the outbreak of the global financial crisis, the Canadian banking system's claims to many countries have decreased or even disappeared. Compared with December 2007, the claims of Canadian banking system to Belgium, France, Germany, Greece, Ireland, Italy, Portugal, Spain, Switzerland and Australia has disappeared in December 2008. Similarly, after the global financial crisis, although the Belgian banking system's claims to many countries did not disappear, the foreign claims declined sharply from $\$ 1632.7$ billion in June 2008 to $\$ 260.5$ billion in December 2012. Therefore, the network connectivity of cross-border banking network shows the evolutionary characteristics of rising before the global financial crisis and declining after the crisis. Observing the node size and connection strength of the cross-border banking network in Figure 2, we find that the banking 
systems of the US and Britain are the most important nodes in the network, and the banking systems of Germany and France are also important. The structure and evolution of cross-border banking network have important implications for risk contagion.

\section{Analysis of empirical results}

Firstly, this study assumes that the government or the central bank does not intervene in policy under pressure scenarios, and simulates how different types of shocks can be transmitted through cross-border banking network: the first group simulation tests the chain effect triggered by debt default (credit shock) in cross-border banking network; the second group simulates the contagion effect of liquidity shocks, and compares it with the first group of shocks. The two groups also considered the trend of cross-border risk contagion after the outbreak of the subprime crisis. Secondly, we consider the contagion effect of policy intervention by the government or the central bank under pressure scenarios ${ }^{9}$.

\subsection{Contagion effects under credit shocks}

In simulating the contagion of credit shocks, it is assumed that any banking system can roll over its matured debts, thus not triggering the sale of assets at reduced prices. Based on the data of June 2008 before Lehman's collapse in the subprime crisis, this paper simulates the impact on the creditor's banking system by assuming that each banking system in the network is bankrupt (i.e. the initial bankruptcy is exogenous) and thus defaults on its debts at different levels of default loss rate.

From Figure 3 (a), the bankruptcy of the banking systems of the US, the UK, the Netherlands, France, Ireland and Germany will cause the bankruptcy of other banking systems in turn as the default loss rate increases. When the default loss rate of the US banking system reaches 0.2 , it will cause bankruptcy of other banking systems. While the default loss rate reaches 0.4 , the UK and Dutch banking systems will cause

\footnotetext{
${ }^{9}$ In the subprime crisis, the U.S. government adopted many policies, such as injecting capital into large commercial banks and investment banks, purchasing troubled assets of banks, and providing loans to banking institutions, etc.
} 
bankruptcy of other banking systems. The banking network losses caused by the bankruptcy of the US and UK banking systems are significantly higher than those of other banking systems (Figure 4). This reflects that many banking systems have large claims on the US and UK banking systems, therefore, once the US and UK banking systems default on their debts, the number of bankruptcy banking systems is large. The bankruptcy of the French and German banking systems will result in the bankruptcy of other banking systems only when the default loss rate is high. The banking network losses caused by the bankruptcy of the two banking systems are second only to those of the US and UK. Foreign debt generally has strong constraints, from some foreign debt crises in history, it can be found that the default loss rate cannot be too high ${ }^{10}$. Therefore, under the credit shock, only the banking systems of the US and UK are of systemic importance. The bankruptcy of the two banking systems can lead to the bankruptcy of other banking systems and cause greater losses to the banking network.

(Figures 3 and 4 are around here)

Network simulation can identify not only the banking system that triggers systemic risk, but also the fragile banking system. From the results of Figure 5 (a), Belgium, the Netherlands and Switzerland banking systems are relatively fragile. At a low default loss rate, the three banking systems will go bankrupt under credit shocks. With the increase of default loss rate, the number of bankruptcies will gradually increase. The reason is that the foreign claims of these three banking systems are too high relative to their own capital level, the ratio of three banking systems are 13.15, 10.38 and 11.84 times respectively, which is much higher than that of other banking

\footnotetext{
${ }^{10}$ Espinosa-Vega \& Sole (2010) assumes that the default loss rate is equal to 1, because cross-border bank claims have a relatively long term, in the short run, bank bankruptcy liquidation is very complex and time-consuming, pricing bank claims (loans) in the secondary market takes time. Similarly, Wells (2004) argues that in network analysis, banks face greater uncertainty in recovering claims, so the default loss rate hypothesis is higher than usual. This is different from the point of view in this paper.
} 
systems. At higher default loss rates, most European banking systems will collapse under credit shocks, which is the consequence of the high leverage of the European banking system when the subprime crisis broke out. In comparison, the banking systems of Turkey, Greece and the US are the most robust. At any level of default loss rate, credit shocks will not lead to the collapse of the three banking systems. The reason is that the foreign claims of the three banking systems are very low relative to their own capital level, which is only $0.34,0.84$ and 0.85 times respectively.

\section{(Figures 5 are around here)}

Network simulation can not only identify the number of bankrupt banking systems, but also estimate the capital loss of banking system after impact. That is to say, even if the bankruptcy of one banking system does not lead to the bankruptcy of other banking systems, network simulation can also measure the impact losses suffered by other banking systems (Table 1), thus clearly showing the impact on other banking systems. For example, the bankruptcy of the US banking system can cause only $1 \%$ capital loss in the Turkish banking system, but $100 \%$ capital loss in the Canadian and Swiss banking systems, leading to the bankruptcy of the two banking systems.

\section{(Table 1 around here)}

Indirect connections provide channels for risk contagion. The simulation finds that, even though the direct connection between two banking systems (claims and liabilities) is not large, if both banking systems are directly connected with the third banking system, then one banking system bankruptcy may cause the third banking system to collapse, and then the other banking system will be impacted or even collapsed. The indirect connection between banks provides a channel for risk contagion. For example, in June 2008, when the default loss rate reaches 1, the bankruptcy of the French banking system will cause seven rounds of contagion and a 
total of 14 banking system failures (Table 2). The first round of contagion only caused the banking system collapse in Belgium and the Netherlands, but the banking system collapse in Belgium and the Netherlands will lead to the following six rounds of contagion which will eventually lead to 14 banking systems collapse. Among them, the third round of German banking system collapse will result in four banking systems collapse, while the front five rounds of nine banking system collapses will eventually lead to the sixth round of British banking system failures, and further led to the collapse of the fourth banking system in the seventh round. Many failed banking systems have relatively low claims on the French banking system compared with their own capital, such as the banking systems of Austria, Australia, Canada, Portugal and Sweden. This result provides important enlightenment. When monitoring the connections between nodes in the banking network, regulatory authorities should pay attention not only to the direct connections between nodes, but also to the indirect connections between nodes, especially to the indirect connections formed by different nodes through connections with hub nodes, which may provide a channel for risk contagion.

\section{(Table 2 around here)}

From the perspective of change trend (Figure 6), during the subprime crisis from June 2007 to June 2009, the contagion effect of credit shocks in cross-border banking network is more serious. When the default loss rate equals 0.6, in June 2007, the bankruptcy of the banking systems of France, the Netherlands, the UK and the US can cause the bankruptcy of other banking systems. However, since December 2007 and December 2008, the bankruptcy of the banking systems of France and the Netherlands will no longer lead to the bankruptcy of other banking systems. From December 2010, the bankruptcy of the British banking system will no longer cause the bankruptcy of other banking systems, which may be related to the deleveraging of the European banking system. After the subprime crisis, the contagion effect of bankruptcy in the US banking system also showed a downward trend. 


\section{(Figures 6 are around here)}

\subsection{Contagion effects under liquidity shocks}

When simulating the contagion of credit shocks, it is assumed that banks can roll over matured debts. However, financial market financing conditions will deteriorate rapidly under pressure scenarios. Financial institutions may take liquidity hoarding behavior based on preventive or strategic motives and lend cautiously. Under extreme pressure, inter-bank market financing is extremely difficult or even frozen, just as in the subprime crisis. Shadow banking system is heavily dependent on short-term wholesale financing, such as asset-backed commercial paper ( $\mathrm{ABCP}$ ) and repo, which is more vulnerable to extension risk and financing liquidity shock. Since July 2007, the issuance of $\mathrm{ABCP}$ has declined dramatically, and shadow banks have been unable to roll over their matured debts. Therefore, the next step of this paper is to further analyze the contagion effect of financing liquidity shock.

When banks suffer from financing liquidity shocks, they will be forced to sell assets if there are no other sources of financing. Usually assets will be sold at a discount, resulting in asset loss and absorbed by bank capital. The ratio of non-extended interbank financing $\rho$ ranges from 0 to 1 , and the asset discount rate $\delta$ ranges from 0 to $2^{11}$. Contagion effects were observed by simulation and at $\rho$ and $\delta$ different parameter levels.

Similarly, the simulation in June 2008 before the collapse of Lehman in the subprime crisis is used as a benchmark. From the simulation results, the banking systems of Germany, France, Britain, Belgium, the Netherlands, Switzerland, Italy, Spain, Japan and the US can cause bankruptcy of other banking systems due to

\footnotetext{
${ }^{11}$ When $\rho=1$, it means that the inter-bank market is completely frozen, the market risk aversion sentiment is high, and the inter-bank debt can not be rolled over at all; when $\delta=2$, it means that assets worth $\$ 3$ are sold according to $\$ 1$, and assets are discounted by two thirds. In the subprime crisis, some subprime derivatives showed similar situations after the collapse of Lehman Brothers.
} 
liquidity shocks under different parameter levels. Among them, the contagion effect caused by German and French banking systems is very serious (Figure 7 (a), Figure 8 (a), Figure 9 (a), Figure 9 (b)). American and Japanese banking systems will cause bankruptcy of other banking systems due to liquidity shocks only under extreme pressure scenarios. The banking systems of Austria, Australia, Canada, Greece, Ireland, Portugal, Sweden and Turkey will not cause bankruptcy of other banking systems because of liquidity shocks. In addition, the simulation results of different periods show that the contagion effect of liquidity shocks in the German banking system surpasses that of the French banking system from June 2007 to June 2009, but from December 2009 to December 2017 after the subprime crisis, the contagion effect of liquidity shocks in the French banking system surpasses that of the German banking system and all other banking systems. After the subprime crisis, the position of German and French banking systems in cross-border banking network has changed. Generally speaking, under the liquidity shock, the banking systems of Germany and France are of the most systematic importance. Under the pressure scenario, the two banking systems can cause more bankruptcies of other banking systems due to the liquidity shock, resulting in the greatest loss to the banking network.

The result of liquidity shock is obviously different from that of credit shock. Under the credit shock, the banking systems of the US and UK are of systemic importance. However, the banking systems of Germany and France are of systemic importance under the liquidity shock. The fundamental reason for this difference lies in the different positions of these banking systems in cross-border banking network. Observing the data of foreign claims and debts of several banking systems, we find that in June 2008, the foreign claims of American and British banking systems were 985.8 and 2781.4 billion US dollars respectively, and the debts was 5996.6 and 3824.8 billion US dollars respectively. By contrast, the foreign claims of German and French banking systems were 3463.3 and 3308.1 billion US dollars respectively, and the debts was 1793.3 and 1375 billion US dollars respectively. Because the debts of American and British banking systems are very large, credit shocks (default on debts) will have a serious impact on other banking systems (creditors). The claims of 
German and French banking systems are very large, and liquidity shocks (non-extended debts) will have a serious impact on other banking systems (debtors).

\section{(Figures 7, 8 and 9 are around here)}

Fragile banking system identification. From the simulation results, Ireland, Greece, the Netherlands, Belgium, Portugal, Austria, Australia, the US banking system is relatively fragile (Figure 10(a) and 10(b)). Once other banking systems do not extend their debts and trigger asset fire-sale, the impact on these banking systems is more obvious, resulting in more bankruptcies of these banking systems. The reason for the fragility of these banking systems is that they rely heavily on other banking systems for financing, and the debt size is relatively large compared with their capital. For example, in June 2008, the ratio of capital to foreign debt in Ireland and Greece was the lowest in all banking systems at 0.12 and 0.16 respectively, and Portugal was also lower at 0.22 , compared with 0.46 in France. In addition, the ratio of capital to foreign debt in the banking systems of the Netherlands and Belgium is as low as 0.16 and 0.18 respectively, and the two banking system are also fragile. Therefore, for a banking institution or the banking system, the debt size is too large and vulnerable to liquidity shocks. Maintaining a moderate debt size is helpful to financial stability.

\section{(Figures 10 is around here)}

After the subprime crisis, the contagion effects caused by liquidity shocks generally showed a downward trend (Figure 11) ${ }^{12}$. For example, at the end of 2010, the banking systems of Germany and France can cause 6 and 4 banking systems bankruptcy because of liquidity shocks respectively (Figure 7 (b) and 8 (b)). The banking systems of Switzerland and Belgium would not cause other banking systems

\footnotetext{
12 Only the US banking system has seen a rise in the number of other banking system failures due to liquidity shocks.
} 
to fail due to liquidity shocks. The decrease of contagion effect may be due to the decrease of connectivity between nodes caused by deleveraging, resulting in the change of network structure.

\section{(Figures 11 is around here)}

\subsection{Comparison of the impact of liquidity shocks and credit shocks}

Previous analysis has assumed that the default loss rate under credit shocks cannot be too high, but the financing conditions of the interbank market may deteriorate sharply under pressure scenario, some interbank financing markets may even freeze, the proportion of interbank debts that cannot be rolled over is very high and result in the fire-sale of assets by banking institutions, if the quality of assets is not very good, the discount rate may be very high (e.g. in the subprime crisis, many financial institutions hold low credit rating CDO tranche $)^{13}$. According to this logic, the contagion effects of credit shock and liquidity shock are compared. For example, under the condition of credit shock, when $\lambda=0.3$, the losses of cross-border banking network caused by default of German and French banking systems are 5379.8 and 4125 billion US dollars, respectively. Under the condition of liquidity shock, the losses caused by German and French banking systems when $\rho=0.3$ and $\delta=0.3$ have exceeded those caused by credit shock, respectively. Other banking systems, such as the UK, the Netherlands, Switzerland, Belgium, Spain, Italy and so on, have similar situations.

Therefore, when the inter-bank financing situation deteriorates, the contagion caused by liquidity shock may be more serious than that caused by credit shock. Moreover, the asset fire-sale caused by liquidity shock will have serious network externality. As long as financial institutions hold the same or similar assets, the fire-sale will inevitably lead to the price decline of these assets, all financial

\footnotetext{
13 According to Longstaff (2010), from the beginning of 2007 to the end of 2008, the AA, A, BBB, BBB subprime mortgage index (constructed according to the $\mathrm{CDO}$ tranches prices of $\mathrm{AA}, \mathrm{A}, \mathrm{BBB}$ and $\mathrm{BBB}$ respectively) dropped from 90 to 100 points to less than 5 points.
} 
institutions suffered losses and it could be serious. Credit shock is due to the strong restraint of foreign creditors, even if the debtor defaults, its default loss rate cannot be high and the losses is limited. This shows that liquidity shock is more important, and regulators should pay more attention to the prevention of liquidity crisis.

\subsection{Change of contagion effects due to risk transfer}

Comparing the simulation results of IBB and URB data under credit shocks, we find that when URB data is used to simulate, even if the default loss rate reaches 1 , the bankruptcy of Irish banking system will not cause other banking systems to fail, but when IBB data is used, the default loss rate reaches 0.8 , and the bankruptcy of Irish banking system will cause other banking systems to fail. When the default loss rate is 0.9 , we use IBB and URB data to simulate and find that the number of bankruptcy banking systems caused by bankruptcy of German banking system is 3 and 14 respectively. When URB data is used to simulate and the default loss rates are 0.5 and 0.6 respectively, the bankruptcy of the British and French banking systems will cause other banking systems to fail, while the corresponding default loss rates are 0.4 and 0.7 respectively under IBB data, Figure 3 (b). Under liquidity shocks, comparing IBB and URB data, in the most extreme stress scenarios $(\rho=1, \delta=2)$, we find that the number of bankrupt banking systems caused by bankruptcy of the British banking system has risen from 5 to 7 , while that of the Swiss banking system has risen from 2 to 3 .

The change of contagion effect reflects the influence of risk transfer on contagions. The inspiration is that not only IBB data but also URB data should be monitored to grasp the change of contagion effect caused by risk transfer more accurately. In the subprime crisis, many financial institutions invest heavily in subprime derivative securities such as CDO, and then buy CDS to provide insurance, thus transferring risk to insurance companies selling CDS. After the subprime crisis broke out, many subprime derivative securities were downgraded and its price plunged, which triggered CDS claims and led to insurance companies selling CDS 
such as AIG to get into trouble. Obviously, CDS has become a bridge of risk contagion.

\subsection{Policy intervention simulation}

The first part of the simulation assumes that the government or the central bank does not intervene in policy under pressure scenario. In reality, the government or the central bank usually relieves financial institutions or markets under pressure scenario. For example, after the outbreak of the subprime crisis, the U.S. government injects capital into large banking institutions, uses various financial instruments (REPO, TAF, PDCF, TSLF) to alleviate the lack of liquidity in financial markets, improve the deposit insurance quota to prevent runs, take over financial institutions, and support mergers and acquisitions of financial institutions, and so on.

After the subprime crisis, the Basel Committee on Banking Supervision (BCBS), on the basis of reflecting on the subprime crisis and the defects of Basel agreement II, issued Basel agreement III and a series of new rules for banking supervision, mainly through strengthening the capital level of banking institutions (including systemically important banks) and maintaining the liquidity of banking institutions to enhance their ability to absorb losses.

Basel agreement III has significantly increased the capital level of banking institutions. In addition to the minimum total capital requirement of $8 \%$, it also introduces conservation buffer capital (2.5\%) and countercyclical buffer capital $(0-2.5 \%)$ and has additional capital requirements (0-3.5\%) for systemically important banks. In this part, capital and liquidity intervention are added to further simulate the risk contagion effect of cross-border banking network under policy intervention.

\subsubsection{Capital intervention simulation}

\section{A. Adding conservation buffer capital}

The capital adequacy ratio of the original banking system is assumed to be $8 \%$. According to the requirements of Basel agreement III, the conservation buffer capital is increased by $2.5 \%$. Therefore, the total capital adequacy ratio reaches $10.5 \%$. Then we simulate the risk contagion effect under credit and liquidity shocks. 
Comparing with the previous simulation results under credit shocks, it is found that when the default loss rate reaches 0.3 , the default of the US banking system will cause one banking system to fail. And the default of the British banking system will cause other banking system to fail only the default loss rate reaches 0.6. Default of German and Irish banking systems will not cause other banking systems to fail even when the default loss rate reaches 1 . The number of other banking system failures caused by defaults in the French banking system dropped sharply from 14 to 2 when the default loss rate reaches 1 . Observing the bankruptcy of the banking system caused the loss of the banking network, we also found that the contagion effect was reduced. Observation the number of a banking system failure caused by the bankruptcies of other banking systems, it is found that the number decreased at any default loss rates. For example, when default loss rate equals 0.5 , the banking systems of Germany, Spain, France, Ireland, Sweden and the UK will no longer fail under the impact of default. At the same time, the bankruptcies number of the banking systems of Belgium, Switzerland, Japan and the Netherlands under default shocks decreased, Figure 5 (b). These results indicate that the increase of capital level enhances the ability of the banking system to withstand shocks.

Under liquidity shocks, compared with the previous simulation results, the contagion effect is reduced. For example, under extreme pressure scenarios $(\rho=1$, $\delta=2$ ), the liquidity shocks of German and French banking systems caused other banking system failures to fall from 12 to 9, 11 to 6, respectively, Figures 7 (c) and 8 (c). The loss of banking network due to liquidity shocks has also been reduced. Observation the number of a banking system failure caused by the bankruptcies of other banking systems, we find that the number of most banking systems have decreased. Similarly, these indicate that the ability of the banking system to withstand liquidity shocks has increased after the capital level of the banking system has increased.

B. Additional capital added to the banking system of systemic importance 
If on the basis of conservation buffer capital, higher capital requirements are put forward for systemically important banks, such as increasing additional capital by $1.5 \%$. According to the simulation results of previous credit and liquidity shocks, the banking systems of the US, Britain, Germany and France have the highest level of systemic importance, adding $1.5 \%$ additional capital to these four banking systems, bringing the total capital level to $12 \%$, while other banking systems maintain $10.5 \%$ capital level. Similarly, on the basis of June 2008 data, the simulation finds that when the default loss rate is equal to 0.6 under credit shocks, the number of other banking system failures caused by defaults in the US and UK banking system dropped further from 6 to 4 and from 11 to 5, respectively. The ability of the British, German and French banking systems to absorb losses increased, and other banking systems failures could no longer lead to the collapse of these three banking systems. Further analysis shows that when the default loss rate is equal to 0.6 , under the original capital level, the failure of the British banking system will result in five rounds of 11 banking system failures (including the German and French banking systems). With the addition of conservation buffer capital, the collapse of the British banking system will result in four rounds of six banking system failures (including the German banking system), and the French banking system will no longer fail. When additional capital is added, the collapse of the British banking system will result in four banking system failures in two rounds. The German and French banking systems will no longer fail, and their loss absorptive capacity will be further enhanced. Similarly, when additional capital is added, the banking system failures in the US will no longer lead to the banking system failures in Britain, Germany and France.

Under liquidity shocks, the ability of German and American banking systems to withstand shocks has been further strengthened. The failures number of Germany and the US banking system caused by the collapse of other banking systems dropped to 0 and 2 respectively. In addition, the cross-border banking network losses caused by different shocks have been alleviated after the capital level has been raised, which indicates that strengthening capital can enhance the ability of banking system to withstand shocks. 


\subsubsection{Liquidity intervention simulation}

Under pressure scenarios, the liquidity of inter-bank market will drop sharply or even freeze, which will make it difficult to roll over interbank debts. Usually, the central bank will intervene in the inter-bank market to enhance liquidity and ensure the financing function of the inter-bank market. Although the means of intervention may be different, the result will either increase the rollover ratio of inter-bank debts or decrease the asset discount rate (i.e. the price of mortgaged assets in financing rises), that is, $\rho$ and $\delta$ go down. Once $\rho$ and $\delta$ decrease, any previous simulation of liquidity shock shows that the number of bankruptcies caused by a banking system failure, the loss to the banking network, the number of bankruptcies caused by other banking systems failure will be reduced, that is, the contagion effect will be reduced.

\section{Conclusion and discussion}

Since the late 1990s, the rapid growth of foreign claims and debts in many countries' banking systems has led to the formation of complex cross-border banking network among banking systems on the basis of interconnection, and provided a channel for cross-border risk contagion. Using BIS's consolidated banking data (IBB and URB) we simulate the risk contagion effect of cross-border banking network under different shock types (credit shock, liquidity shock) based on the network analysis mothed. The conclusions are as follows:

Based on the June 2008 point before Lehman Brothers collapsed in the process of subprime crisis and IBB data simulation, it is found that under the condition of credit shocks, the banking system of the US and UK has the most systemic importance (the simulation results of other time points are consistent). At a lower default loss rate, the default of debt of the US and UK banking system can cause bankruptcy of other banking systems and lead to banking network great loss. The ability of the banking system to withstand external shocks is directly related to the size and concentration of its claims. The banking systems of the Netherlands, Switzerland and Belgium are the most vulnerable, which is related to its high level of claims relative to its capital and, thus their ability to withstand external shocks is 
weak. The banking systems of the US, Greece and Turkey are the most robust, credit shocks will not lead to the collapse of these three banking systems at any level of default loss rate. The reason is that the claims of these three banking systems to other banking systems are relatively low relative to their capital levels, so they are highly immune to external shocks.

Under the condition of liquidity shocks, the contagion effects caused by German and French banking systems are the most serious, so these two banking systems are of the most systemic importance. During the subprime crisis, the contagion effects of German banking system exceeded those of French banking system, but after the subprime crisis, the reverse is true. This shows that the position of German and French banking systems in the cross-border banking network has changed after the subprime crisis. Under the liquidity and credit shock, the banking system with systemic importance is different, because the banking system is in different positions in the cross-border banking network. The foreign claims of the US and British banking systems are smaller than foreign debts, while German and French banking systems have larger foreign claims than foreign debts. The banking systems of Ireland, Greece, the Netherlands, Belgium, Portugal, Austria, Australia and the US are relatively vulnerable to liquidity shocks because they rely heavily on other banking systems for financing, and the debt size is relatively large compared with their capital level. Because of the strong restraint of foreign creditors, the default loss rate of credit shocks cannot be high even if the debtor defaults. Under extreme pressure scenarios, asset fire-sale caused by deterioration of inter-bank financing will have serious network externality and serious contagion effects. Therefore, liquidity shocks are more important. There are some differences between URB and IBB data simulation results, reflecting the impact of risk transfer on contagion effects. In addition, according to the data simulation after the subprime crisis, it is found that the contagion effects of credit shock and liquidity shock both show a downward trend, which may be related to the deleveraging of many banking systems (the decline of claims of the banking system). 
When conservation buffer capital is added to the banking system, the capital level is raised, and the contagion effects of credit shock and liquidity shock are alleviated. If additional capital is added to the banking system of systemic importance, the stability of the banking network will be further enhanced, which indicates that strengthening the capital base of the banking system will help to enhance its ability to absorb losses. Under the pressure scenario, if the government or the central bank intervene in the interbank market, enhance the liquidity of the market, alleviate the problem of interbank debt rollover, increase the ratio of interbank debt rollover or decrease the asset discount rate, the contagion effect of liquidity shock will be reduced.

The empirical findings of this paper have some important policy implications. Ensuring systemically important banking systems' stability is crucial to the stability of cross-border banking network. Different time points and different types of simulations based on types of shocks (credit and liquidity) show that the banking systems of the US, Britain, Germany and France have most systemic importance. Once these banking systems are unstable, it will bring serious negative impact on others banking systems. That was the case during the subprime crisis. Basel agreement III imposes higher capital requirements on systemically important banks in order to enhance their ability to absorb losses and thus enhance the stability of the entire banking network.

The foreign claims of the banking system should not be too high and concentrated. The simulation finds that some banking systems are vulnerable to credit shocks because their claims to other banking systems are too high and concentrated relative to their own capital levels. Once the debtor defaults, these banking systems are severely damaged or even bankrupt, such as the Belgian, Swiss and Dutch banking systems. Therefore, maintaining a moderate level of foreign claims in the banking system can help the banking system resist the impact of credit shocks.

Interbank debt remains at a reasonable level. Simulations show that some banking systems are vulnerable to liquidity shocks because they depend heavily on other banking systems for financing, and the size of their debt is relatively large 
compared with their capital. Under pressure scenario, once other banking systems fail to roll over their debt and trigger asset fire-sale, these banking systems will lose a lot, such as Ireland, Greece, the Netherlands, Belgium, Portuguese banking system. Therefore, maintaining a moderate level of interbank debt can help the banking system withstand the impact of liquidity shocks.

In view of the fact that most countries have not released the data of foreign claims of the banking system and have not included the sample of cross-border banking network for simulation, and some countries (regions) may have larger foreign claims of the banking system, such as Luxembourg, Cayman Islands, Hong Kong, Singapore, China, etc. At the same time, some countries such as Brazil, India, Korea and other countries have difficulty in obtaining capital data of the banking system. If these data can be disclosed and acquired in the future, the importance of this simulation analysis method as a tool for monitoring cross-border banking network risk will be more meaningful. 


\section{References:}

Acemoglu, D., Ozdaglar, A. and A.Tahbaz-Salehi, 2015, "Systemic risk and stability in financial networks", American Economic Review 105, 564-608.

Acharya, V.V. and S.Steffen, 2015, "The "greatest" carry trade ever? Understanding eurozone bank risks", Journal of Financial Economics 115, 215-236.

Acharya, V.V., Gale, D. and T.Yorulmazer, 2011, "Rollover risk and market freezes", Journal of Finance 66, 1177-1209.

Acharya, V.V., Engle, R. and M.Richardson, 2012, "Capital shortfall: a new approach to ranking and regulating systemic risks", American Economic Review 102, 59-64.

Aiyar, S., 2012, "From financial crisis to great recession: the role of globalized banks", American Economic Review 102, 225-230.

Allen, F. and D.Gale, 2000, "Financial contagion", Journal of Political Economy 108(1):1-33.

Allen, F. and E.Carletti, 2013, "What is systemic risk? ", Journal of Money, Credit and Banking $45,121-127$.

Amundsen, E. and H. Arnt, 2005, "Contagion risk in the Danish interbank market", Denmark National Bank Working paper 25.

Bank for International Settlements (BIS), 2017. http://stats.bis.org/statx/toc/CBS.html. (Get access to the website on $19^{\text {th }}$, December 2017).

Blavarg, M. and P. Nimander, 2002, "Inter-Bank Exposures and Systemic Risk", Sveriges Riksbank, Economic Review 2:19-45.

Chan-Lau, J., 2010, "Balance sheet network analysis of too-connected-to-fail risk in global and domestic banking systems," IMF Working Paper No. 10/107.

Chan-Lau, J., M. Espinosa, K. Giesecke and J. Solé, 2009, “Assessing the Systemic Implications of Financial Linkages", Chapter 2 of Global Financial Stability Report, IMF, April.

Chen, Y., Shi, Y., Wei, X. and L. Zhang, 2014, "Domestic systemically important banks: a quantitative analysis for the Chinese banking system", Mathematical Problems in Engineering 4, 1-19.

Chinazzi, M., Fagiolo, G., Reyes, J.A. and S.Schiavo, 2012, "Post-Mortem Examination of the International Financial Network", Department of Economics Working Papers 1202, Department of Economics, University of Trento, Italia.

Degryse, H., Elahi, M. and M. Penas, 2010, "Cross-border exposures and financial contagion", International Review of Finance 10 (2), 209-240.

Degryse, H. and G. Nguyen, 2007, "Interbank Exposures: An Empirical Examination of Systemic Risk in the Belgian Banking System”, International Journal of Central Banking 3(2): 123-172.

Elliott, M., Golub, B. and M.Jackson, 2014, "Financial networks and contagion", American Economic Review 104, 3115-3153.

Elsinger, H., A. Lehar and M. Summer, 2006a, "Risk Assessment of Banking System", Management Science 52(9):1301-1314.

Elsinger, H., A. Lehar and M. Summer, 2006b, "Using market information for banking system risk assessment”, International Journal of Central Banking 2(1):137-165.

Espinosa-Vega, M. and J. Solé, 2010, "Cross-Border Financial Surveillance: A Network Perspective", IMF Working Paper No. 10/105.

Frisell, L., M. Holmfeld, O. Larsson, M. Omberg and M. Persson, 2007, "State-dependent 
contagion risk: using micro data from Swedish banks", Mimeo.

Furfine, C., 2003, "Interbank Exposures: Quantifying the Risk of Contagion”, Journal of Money, Credit and Banking 35(1):111-128.

Garratt, R.J., Mahadeva, L. and K.Svirydzenka, 2014, "The great entanglement: The contagion capacity of the international banking network just before the 2008 crisis", Journal of Banking \& Finance (49): 367-385.

Geng, N. and P. N'Diaye, 2012, "Determinants of corporate investment in china: evidence from cross-country firm level data", IMF Working Papers 12(80).

Georg, C.P., 2013, "The effect of the interbank network structure on contagion and common shocks", Journal of Banking \& Finance 37(7): 2216-2228.

Glasserman, P. and H. Young, 2015, "How likely is contagion in financial networks?", Journal of Banking \& Finance 50(1): 383-399.

Guerrero-Gómez, S. and F. Lopez-Gallo, 2004, "Interbank exposures and systemic risk assessment: an empirical analysis for the Mexican banking sector", Mimeo.

Kubelec, C. and F. Sa, 2012, "The geographical composition of national foreign balance sheets: 1980-2005”, International Journal of Central Banking 8 (2), 143-189.

Li, J., Wei, M. and B. Lin, 2016, 'Does top executives' us experience matter? Evidence from us-listed Chinese firms", China Journal of Accounting Research 9(4), 267-282.

Liang, N., 2013, "Systemic risk monitoring and financial stability", Journal of Money, Credit and Banking 45, 129-135.

Panageas, S., 2010, "Bailouts, the incentive to manage risk, and financial crises", Journal of Financial Economics 95, 296-311.

Longstaff, F., 2010, "The subprime credit crisis and contagion in financial markets", Journal of Financial Economics 97(3): 436-450.

Lublóy, A., 2005, "Domino Effect in the Hungarian Interbank Market", Hungarian Economic Review LII(4):377-401.

Memmel, C. and I. Stein, 2008, "Contagion in the German Interbank Market," (Frankfurt: Deutsche Bundesbank).

Minoiu, C. and J.A.Reyes, 2013, “A network analysis of global banking:1978-2010”, Journal of Financial Stability 9(2), 168-184.

Mistrulli, P., 2007, “Assessing Financial Contagion in the Interbank Market:Maximum Entropy versus Observed Interbank Lending Patterns", Temi di discussione (Economic working papers) 641, Bank of Italy.

Müller, J., 2006, "Interbank Credit Lines as a Channel of Contagion”, Journal of Financial Services Research 29(1):37-60.

Paltalidis, N., D. Gounopoulos, R. Kizys and Y. Koutelidakis, 2015, "Transmission channels of systemic risk and contagion in the European financial network", Journal of Banking \& Finance 61, Supplement 1: s36-s52.

Sheldon, G. and M. Maurer, 1998, "Interbank Lending and Systemic Risk: An Empirical Analysis for Switzerland”, Swiss Journal of Economics and Statistics 134 (4.2): 685-704.

Toivanen, M., 2009, "Financial interlinkages and risk of contagion in the Finnish interbank market”, Bank of Finland Discussion Paper 6/2009.

Tonzer, L., 2015, “Cross-border interbank networks, banking risk and contagion”, Journal of Financial Stability 18 (6):19-32. 
Upper, C. and A. Worms, 2004, "Estimating bilateral exposures in the German interbank market: Is there a danger of contagion?", European Economic Review 48(4):827-849.

Van Lelyveld, I. and F. Liedorp, 2006, "Interbank Contagion in the Dutch Banking Sector: A Sensitivity Analysis", International Journal of Central Banking 2(2):99-133.

Wells, S., 2004, "Financial Interlinkages in the United Kingdom's Interbank Market and the Risk of Contagion", Bank of England Working Paper No. 230. 
Table 1: The proportion of capital loss caused by credit shock between banking systems

(IBB, $\lambda=0.3,2008 / 6$ )

\begin{tabular}{|c|c|c|c|c|c|c|c|c|c|c|c|c|c|c|c|c|c|c|}
\hline & AT & $\mathrm{AU}$ & $\mathrm{BE}$ & $\mathrm{CA}$ & $\mathrm{CH}$ & $\mathrm{DE}$ & ES & FR & GR & IE & IT & JP & NL & PT & SE & TR & UK & US \\
\hline $\begin{array}{c}\text { Triggering } \\
\text { system }\end{array}$ & \multicolumn{18}{|c|}{ Capital loss ratio of the impact banking system（\%) } \\
\hline AT & 0 & 0 & 3 & 1 & 4 & 7 & 1 & 1 & 0 & 2 & 10 & 1 & 2 & 0 & 1 & 1 & 0 & 0 \\
\hline $\mathrm{AU}$ & 1 & 0 & 2 & 4 & 6 & 4 & 0 & 3 & 0 & 3 & 0 & 6 & 17 & 0 & 2 & 0 & 6 & 2 \\
\hline $\mathrm{BE}$ & 1 & 0 & 0 & 1 & 4 & 3 & 2 & 7 & 0 & 3 & 1 & 3 & 28 & 1 & 2 & 1 & 2 & 1 \\
\hline CA & 1 & 0 & 2 & 0 & 4 & 3 & 0 & 1 & 0 & 3 & 0 & 5 & 8 & 0 & 1 & 0 & 3 & 2 \\
\hline $\mathrm{CH}$ & 3 & 1 & 6 & 1 & 0 & 4 & 1 & 3 & 0 & 1 & 1 & 2 & 4 & 1 & 3 & 0 & 1 & 0 \\
\hline DE & 17 & 2 & 28 & 3 & 17 & 0 & 6 & 15 & 1 & 13 & 29 & 15 & 33 & 5 & 35 & 2 & 5 & 2 \\
\hline ES & 3 & 0 & 18 & 1 & 3 & 17 & 0 & 10 & 0 & 10 & 2 & 3 & 22 & 17 & 4 & 0 & 5 & 1 \\
\hline FR & 4 & 2 & 43 & 3 & 21 & 14 & 7 & 0 & 1 & 8 & 6 & 11 & 30 & 5 & 6 & 0 & 8 & 1 \\
\hline GR & 1 & 0 & 4 & 0 & 11 & 2 & 0 & 4 & 0 & 3 & 1 & 1 & 3 & 4 & 0 & 0 & 0 & 0 \\
\hline IE & 3 & 1 & 39 & 4 & 7 & 13 & 2 & 6 & 0 & 0 & 2 & 4 & 8 & 5 & 3 & 0 & 7 & 1 \\
\hline IT & 6 & 0 & 19 & 1 & 7 & 14 & 5 & 26 & 0 & 15 & 0 & 6 & 16 & 3 & 1 & 0 & 3 & 1 \\
\hline $\mathrm{JP}$ & 0 & 0 & 1 & 1 & 26 & 5 & 0 & 11 & 0 & 5 & 0 & 0 & 7 & 0 & 0 & 0 & 3 & 3 \\
\hline NL & 5 & 1 & 86 & 2 & 9 & 10 & 6 & 7 & 1 & 5 & 2 & 7 & 0 & 3 & 5 & 1 & 3 & 2 \\
\hline $\mathrm{PT}$ & 1 & 0 & 3 & 0 & 1 & 3 & 8 & 2 & 0 & 2 & 1 & 0 & 3 & 0 & 0 & 0 & 1 & 0 \\
\hline $\mathrm{SE}$ & 0 & 0 & 1 & 1 & 2 & 2 & 0 & 1 & 0 & 2 & 0 & 1 & 2 & 0 & 0 & 0 & 1 & 0 \\
\hline TR & 1 & 0 & 5 & 0 & 1 & 1 & 0 & 1 & 14 & 0 & 0 & 0 & 4 & 1 & 0 & 0 & 1 & 0 \\
\hline UK & 10 & 29 & 78 & 23 & 64 & 41 & 36 & 24 & 6 & 74 & 6 & 22 & 50 & 7 & 25 & 4 & 0 & 8 \\
\hline US & 10 & 11 & 64 & 100 & 100 & 48 & 12 & 40 & 2 & 34 & 5 & 84 & 88 & 6 & 21 & 1 & 42 & 0 \\
\hline
\end{tabular}


Table 2: The contagion effect of the bankruptcy of French banking system (IBB, $\lambda=1,2008 / 6$ )

\begin{tabular}{c|c|c|c|c|c|c|c}
\hline Triggering system & \multicolumn{6}{|c}{ Contagion rounds and the bankruptcy of the banking system } \\
\hline FR & R1 & R2 & R3 & R4 & R5 & R6 & R7 \\
\hline & BE & CH & DE & AT & IE & UK & AU \\
& NL & & & IT & & & CA \\
& & & JP & & & ES \\
& & & & SE & & & PT \\
\hline
\end{tabular}

Figure 1: Change of foreign claims in seven developed countries' banking system (Data sources: BIS)

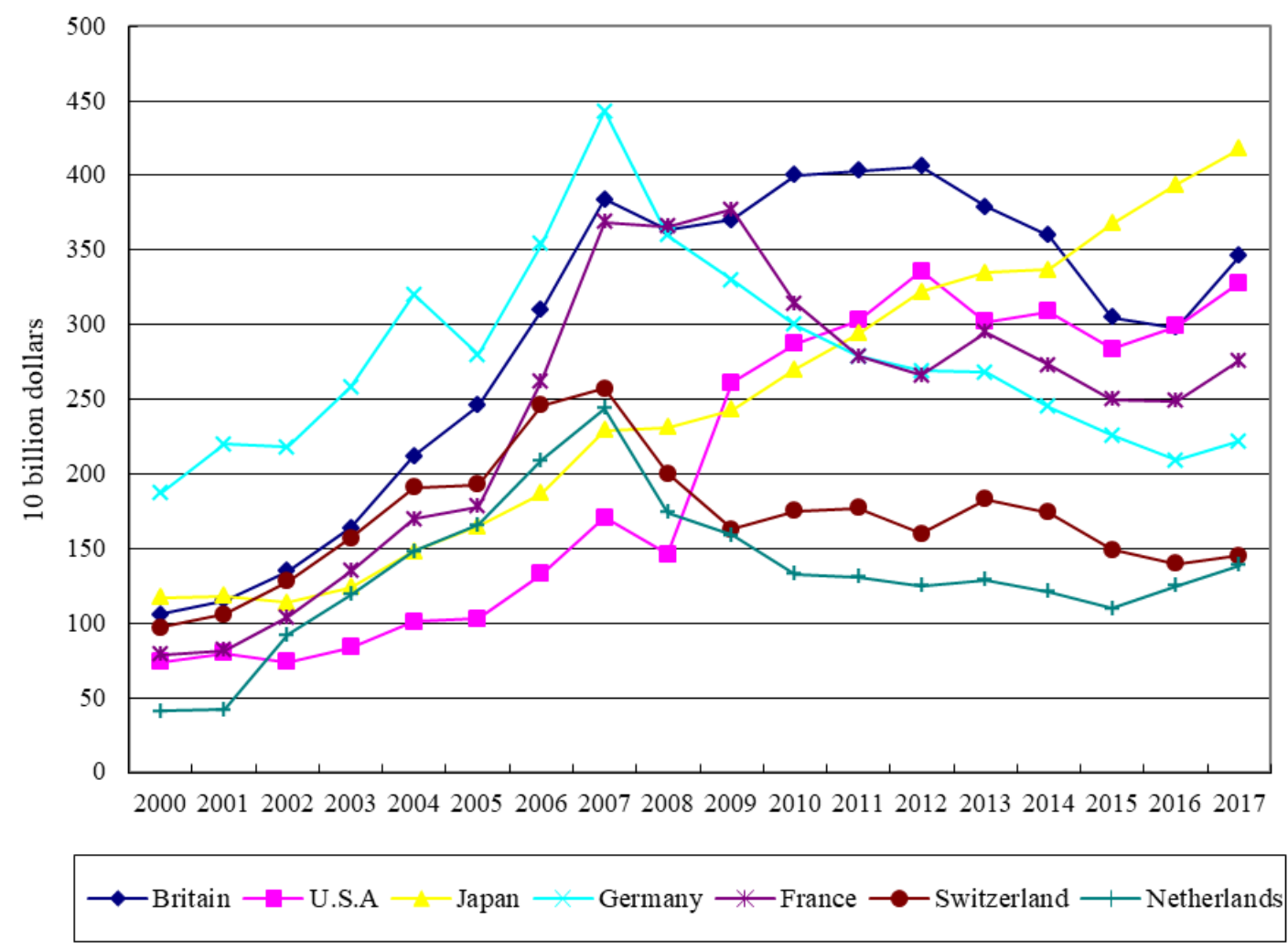


Figure 2: Cross-border banking network (2008/6)

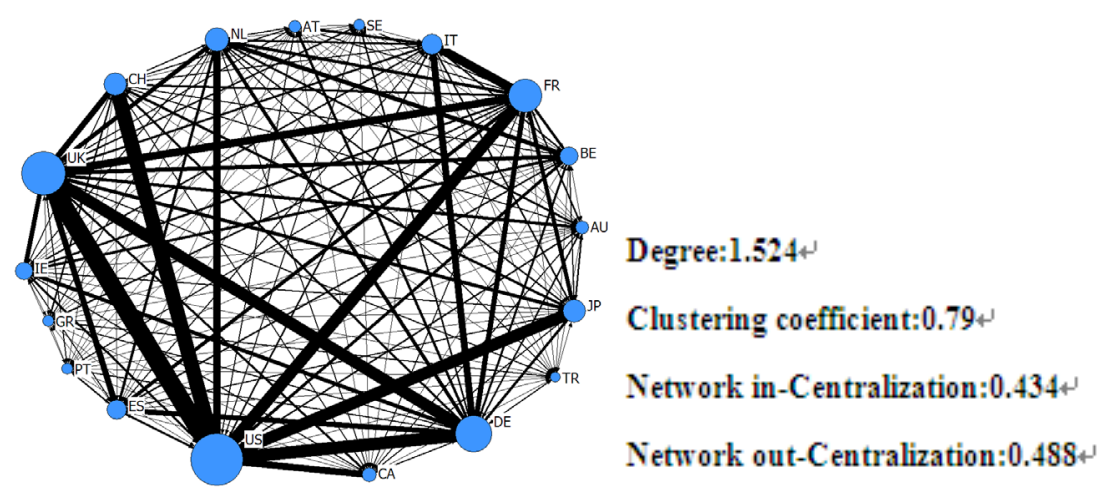


Figure 3: Number of failed banking systems caused by credit shock
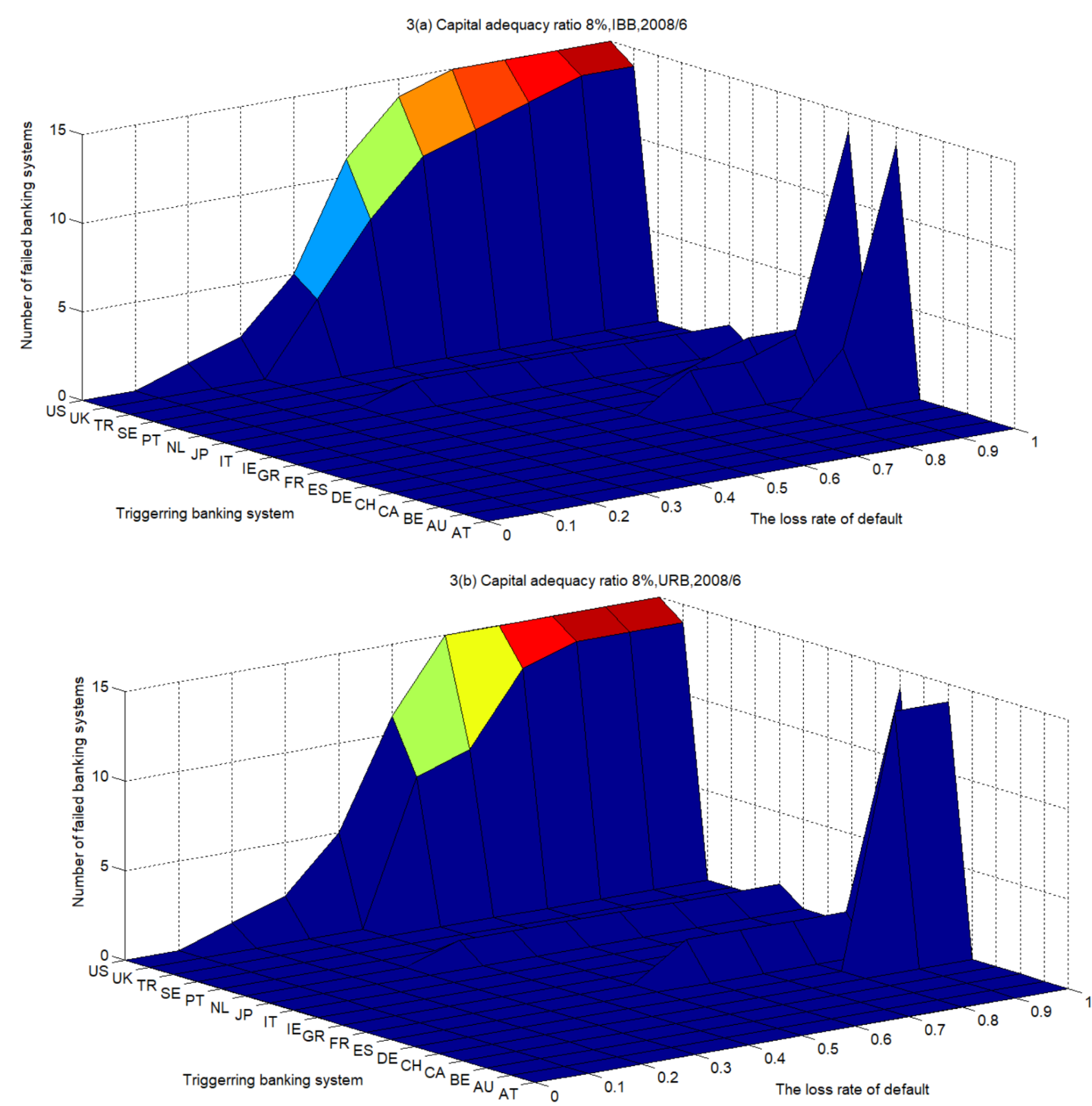
Figure 4: The amount of banking network loss caused by credit shock

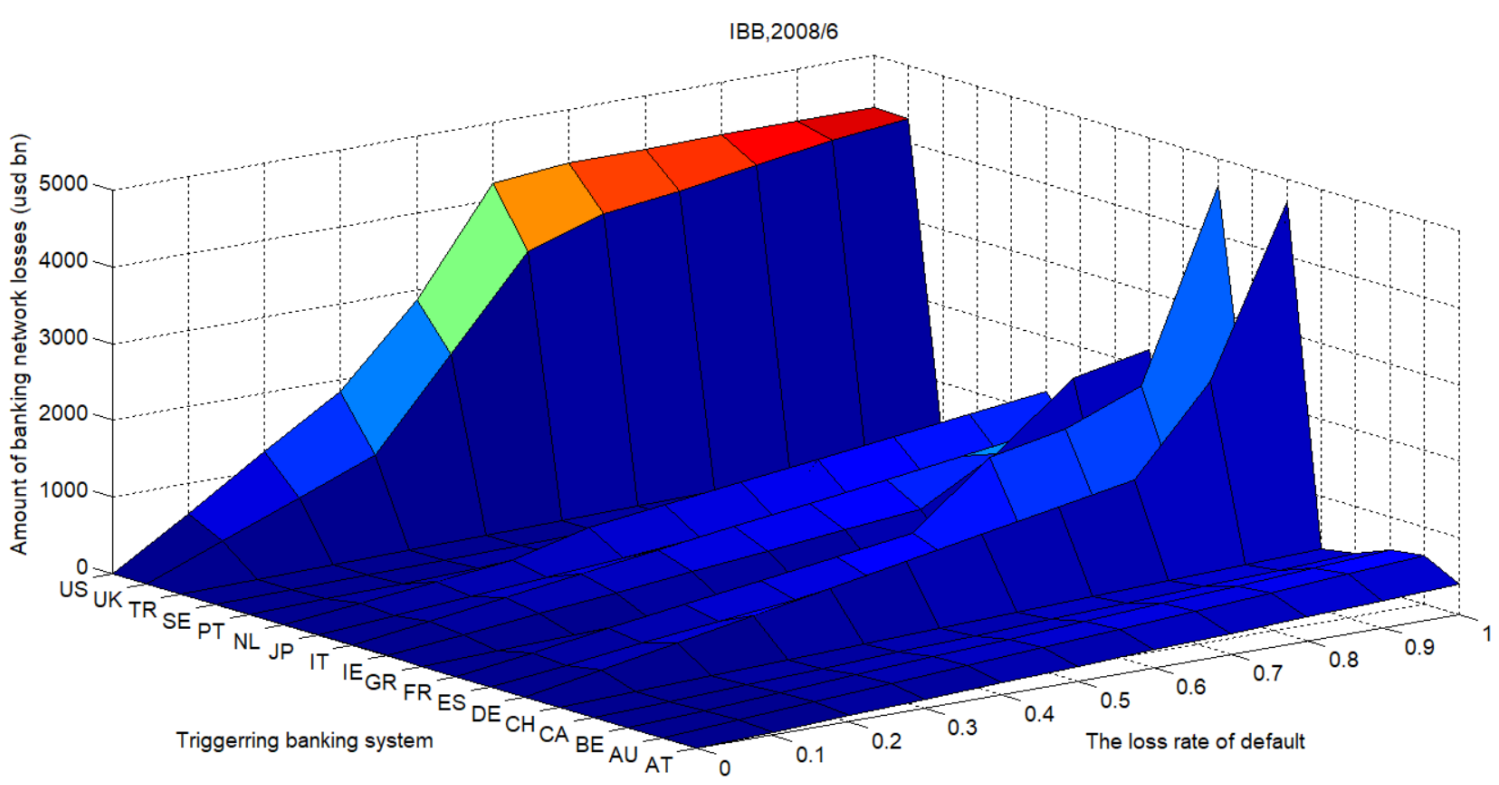

Figure 5: Number of banking system failures due to credit shock

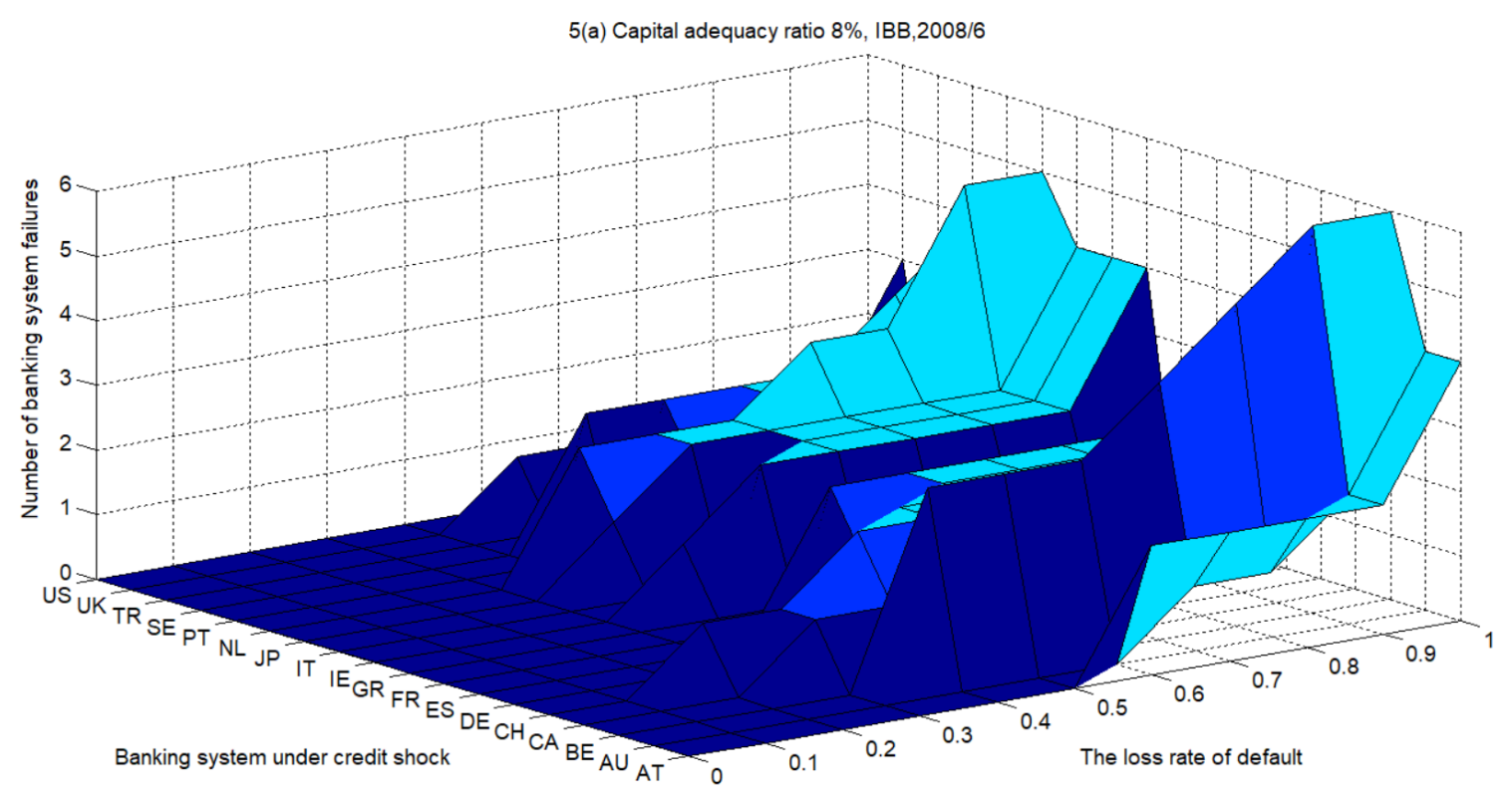




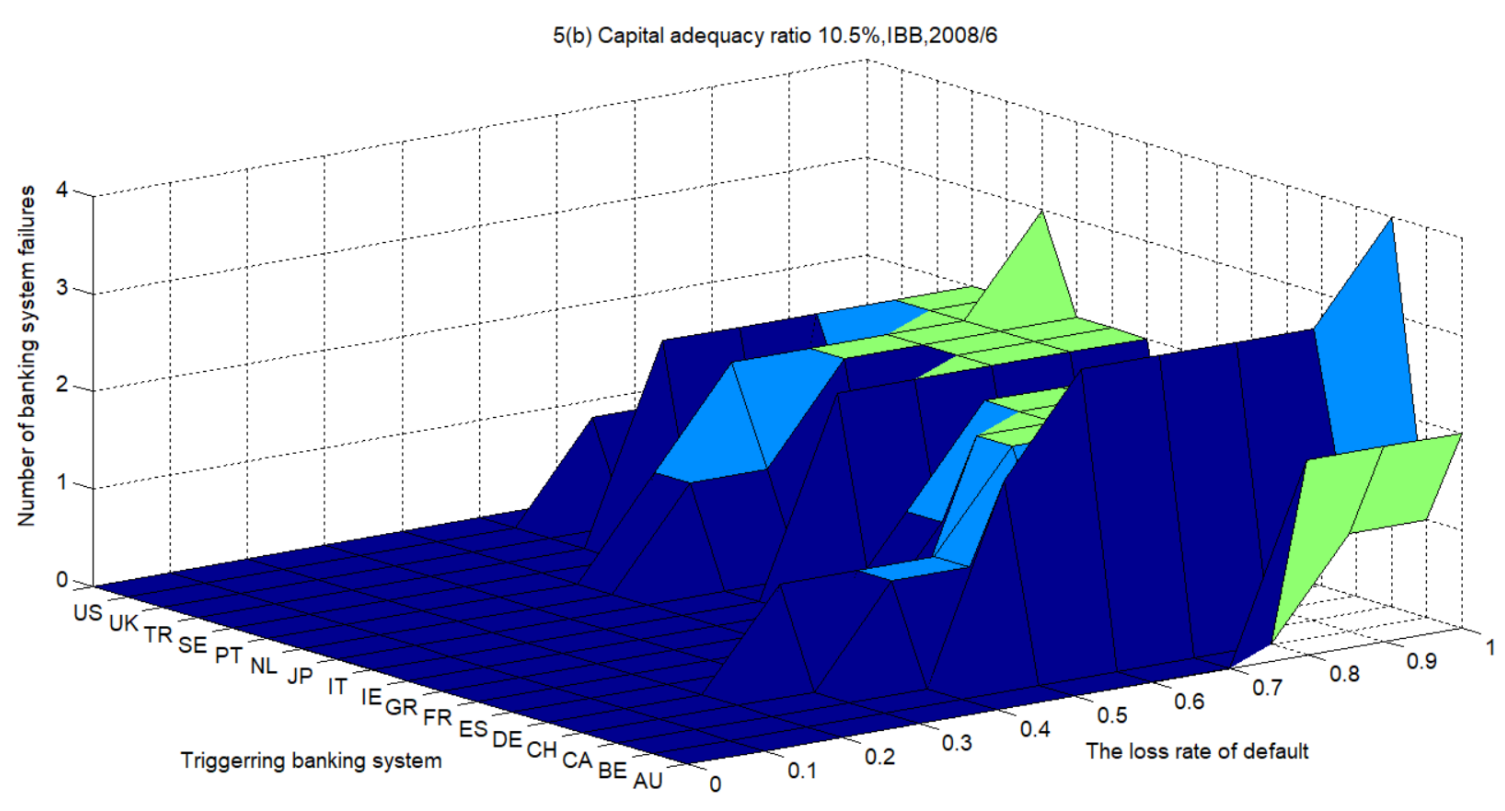

Figure 6: Number of failed banking systems caused by credit shock (2007-2017)

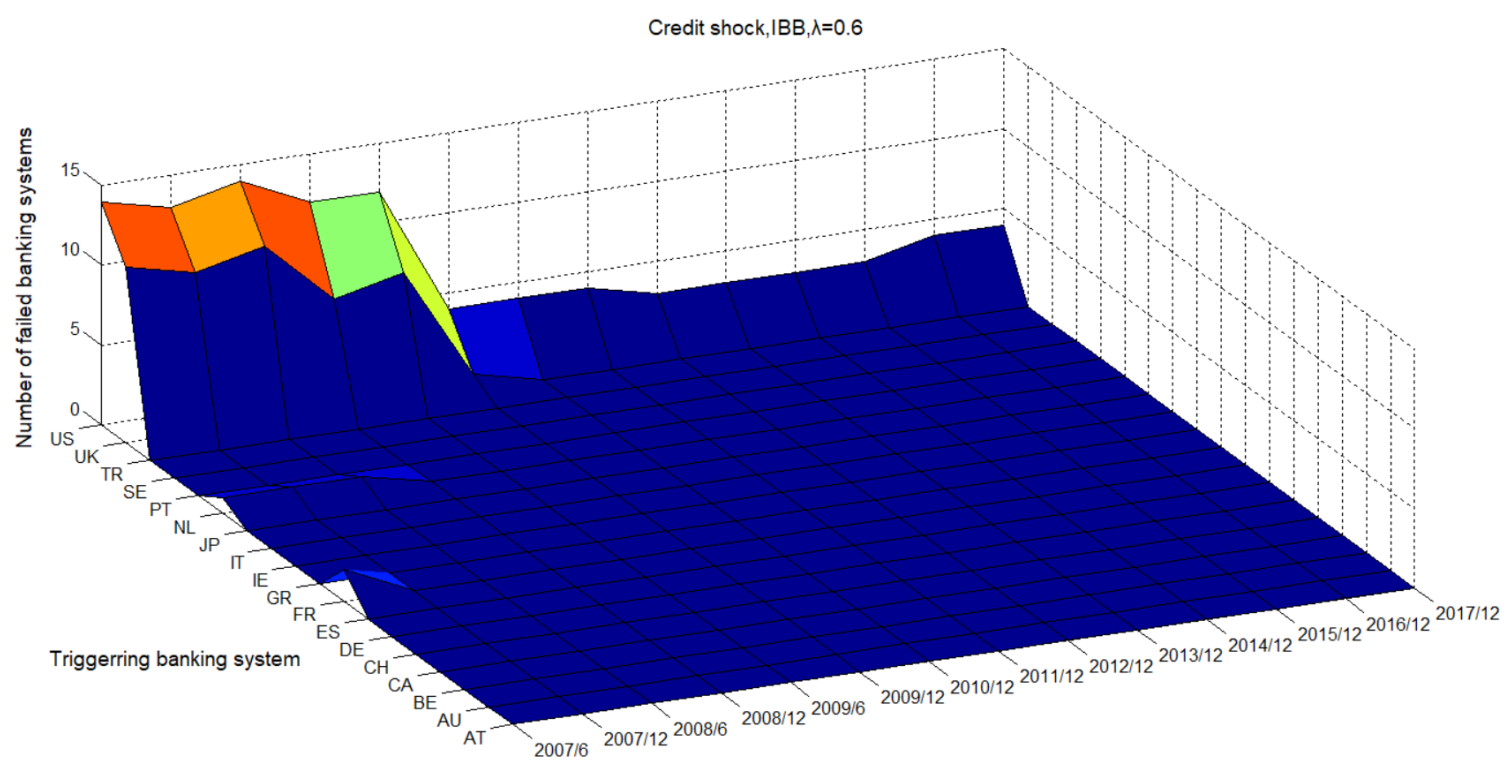




$$
=
$$




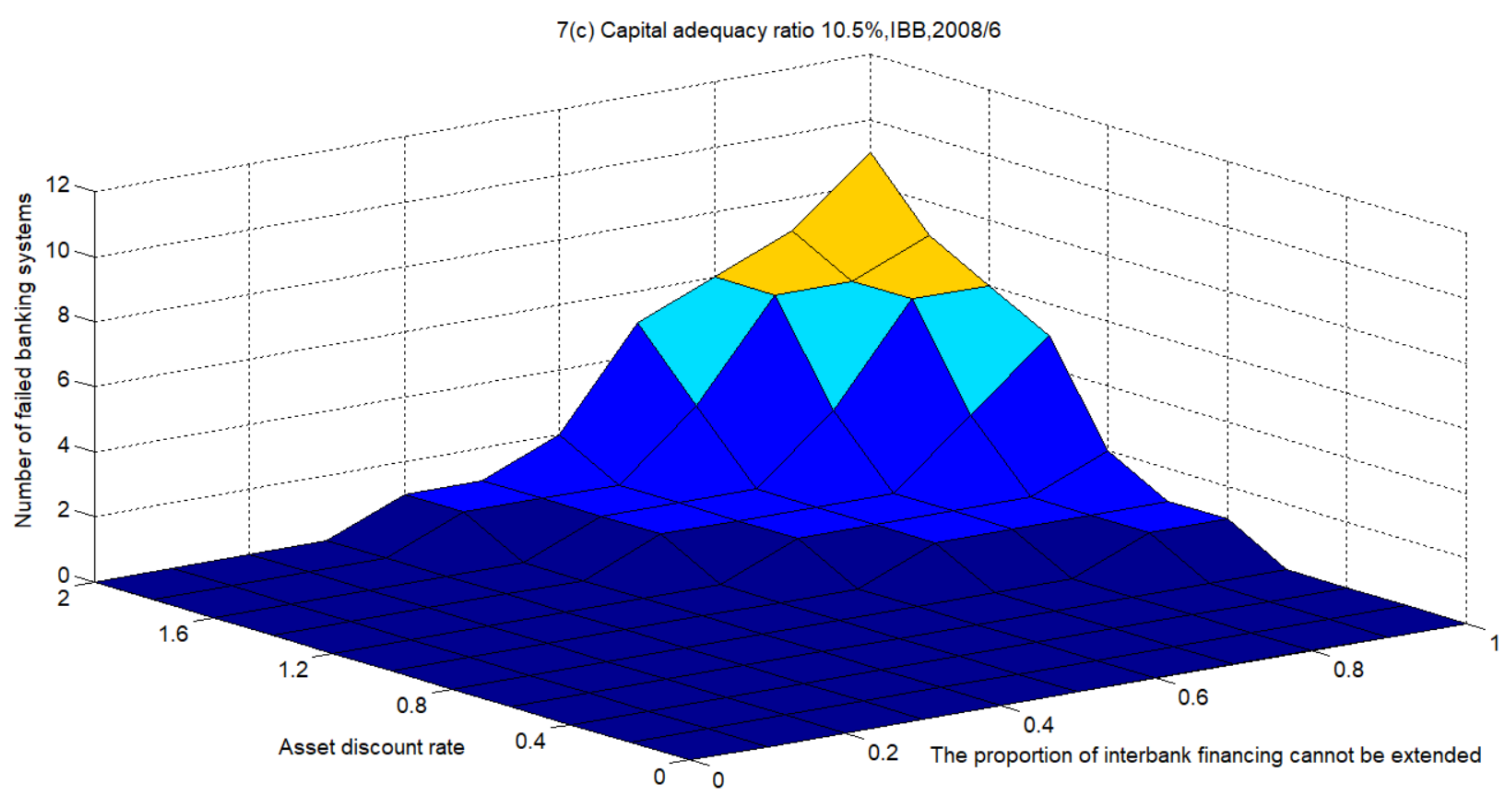

Figure 8: Number of failed banking systems caused by default of French banking system

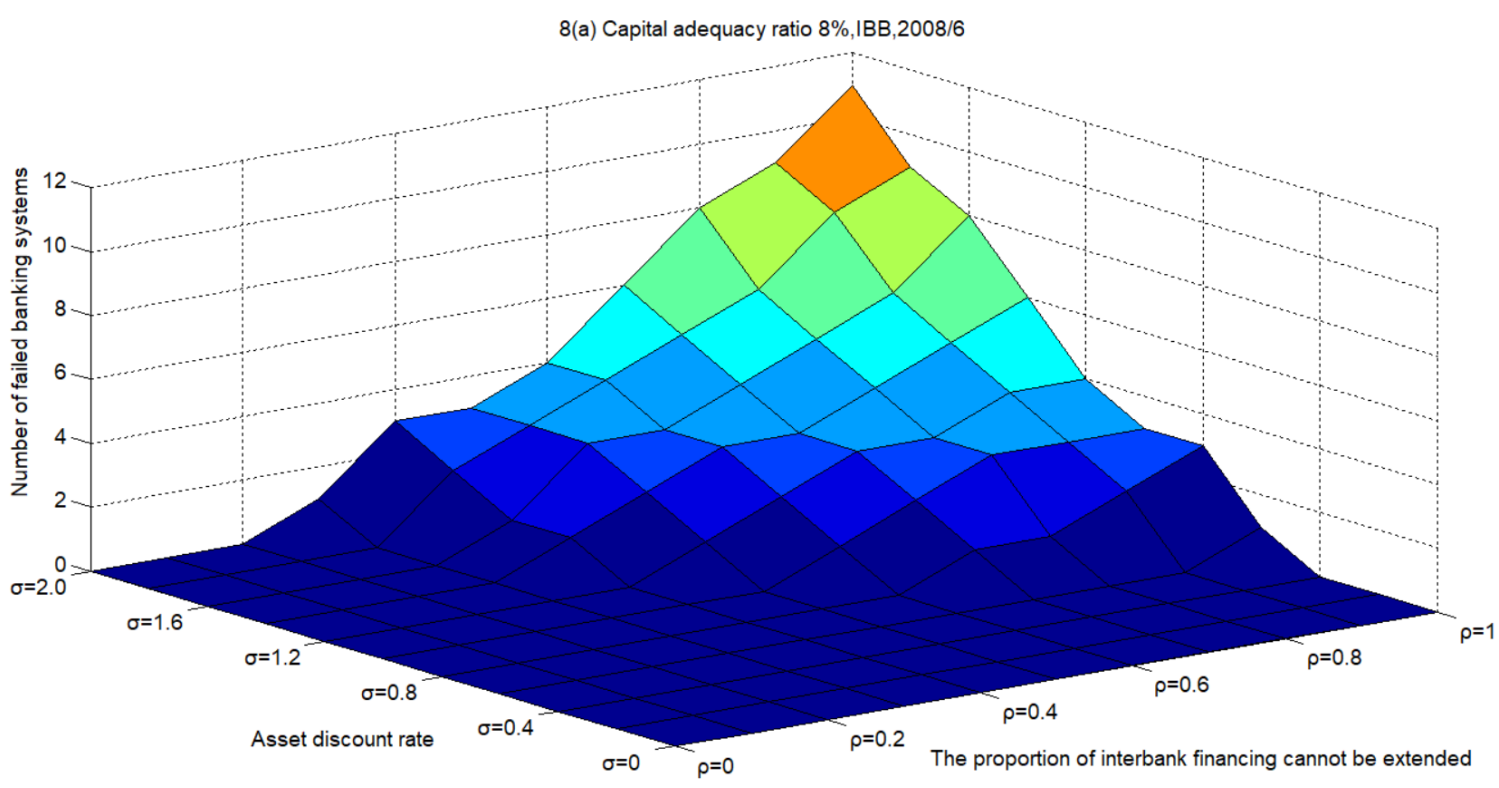


[Type here]
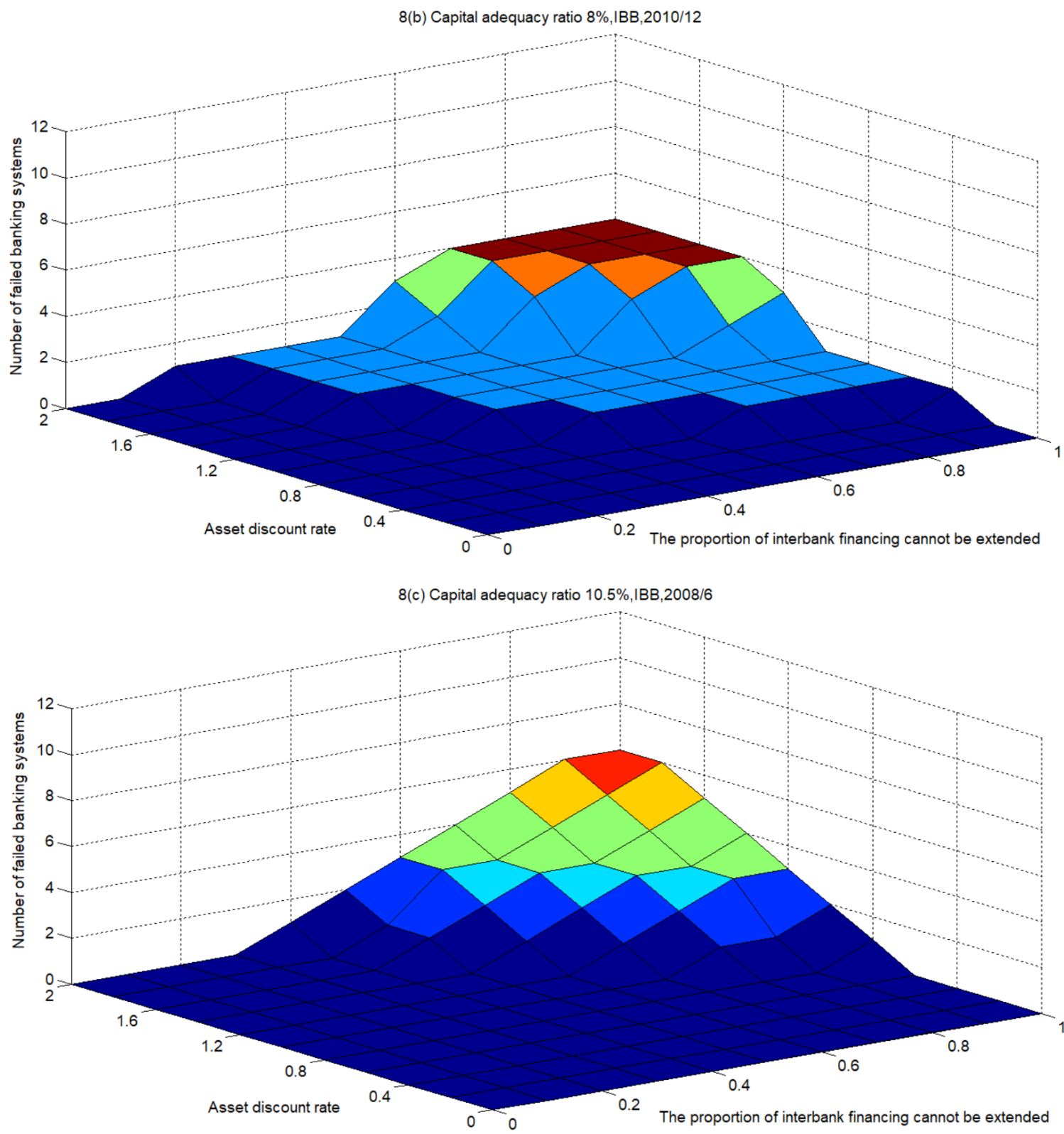
Figure 9: Banking network loss caused by liquidity shock of German and French banking

\section{system}

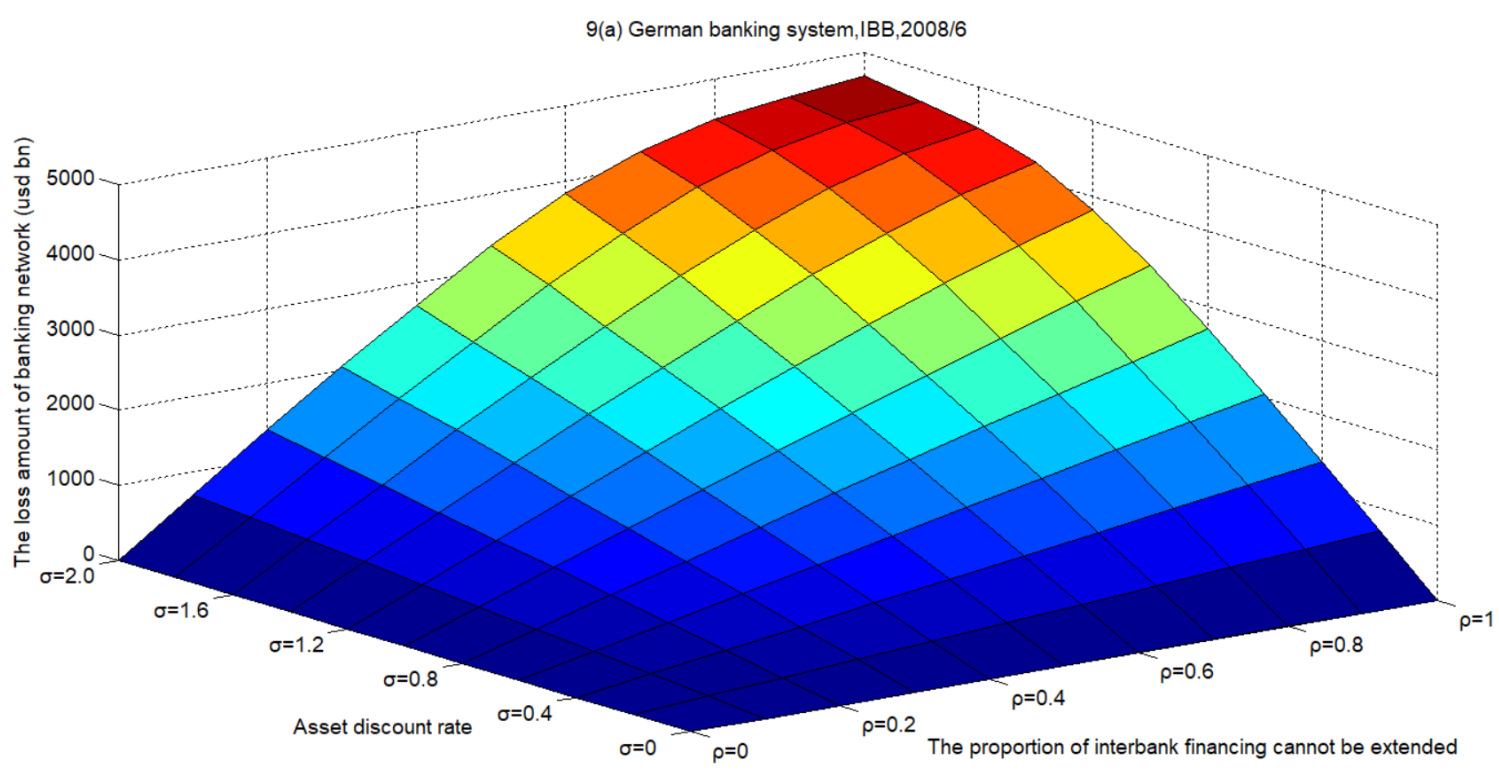

9(b) French banking system,IBB,2008/6

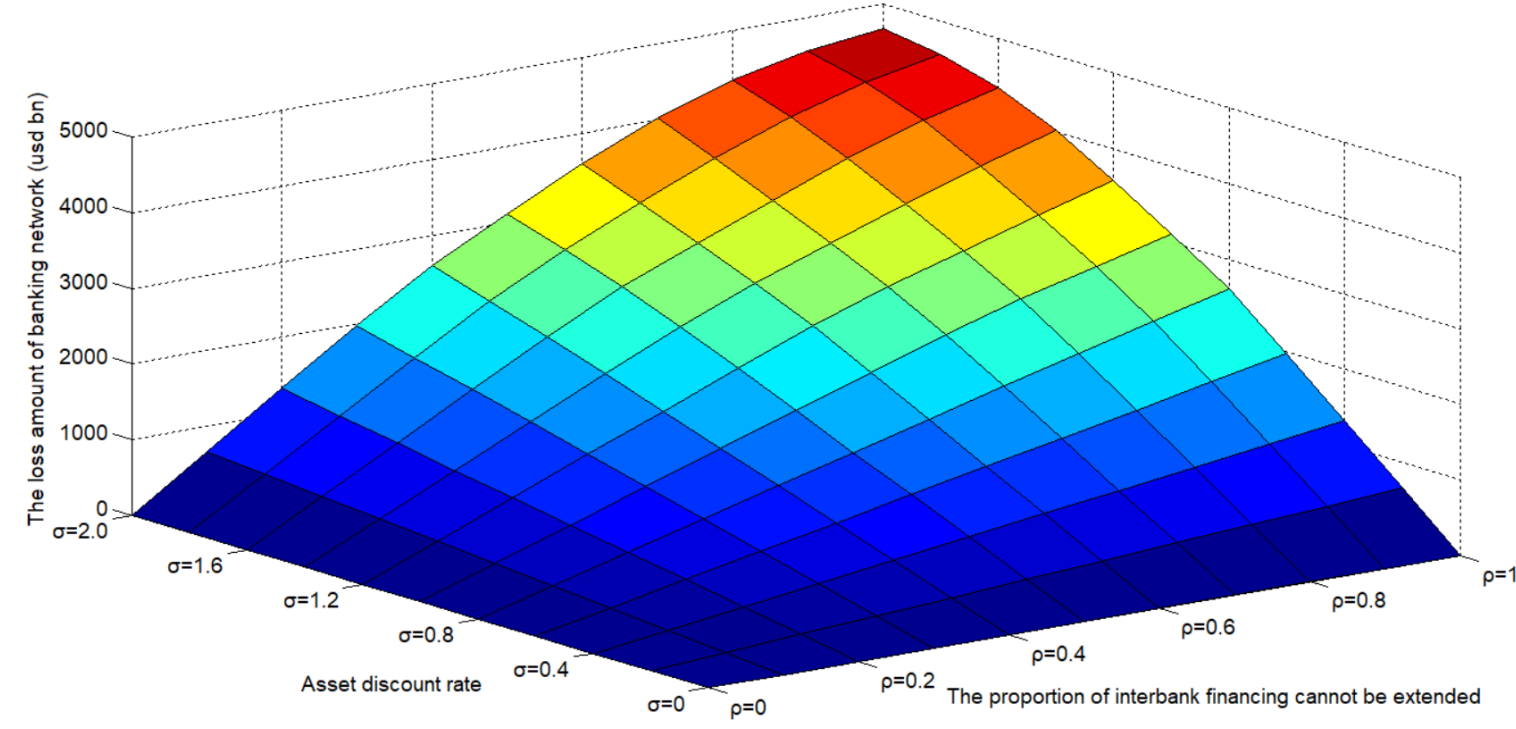


Figure 10: Number of bankruptcies of Irish and Greek banking system due to liquidity

shock

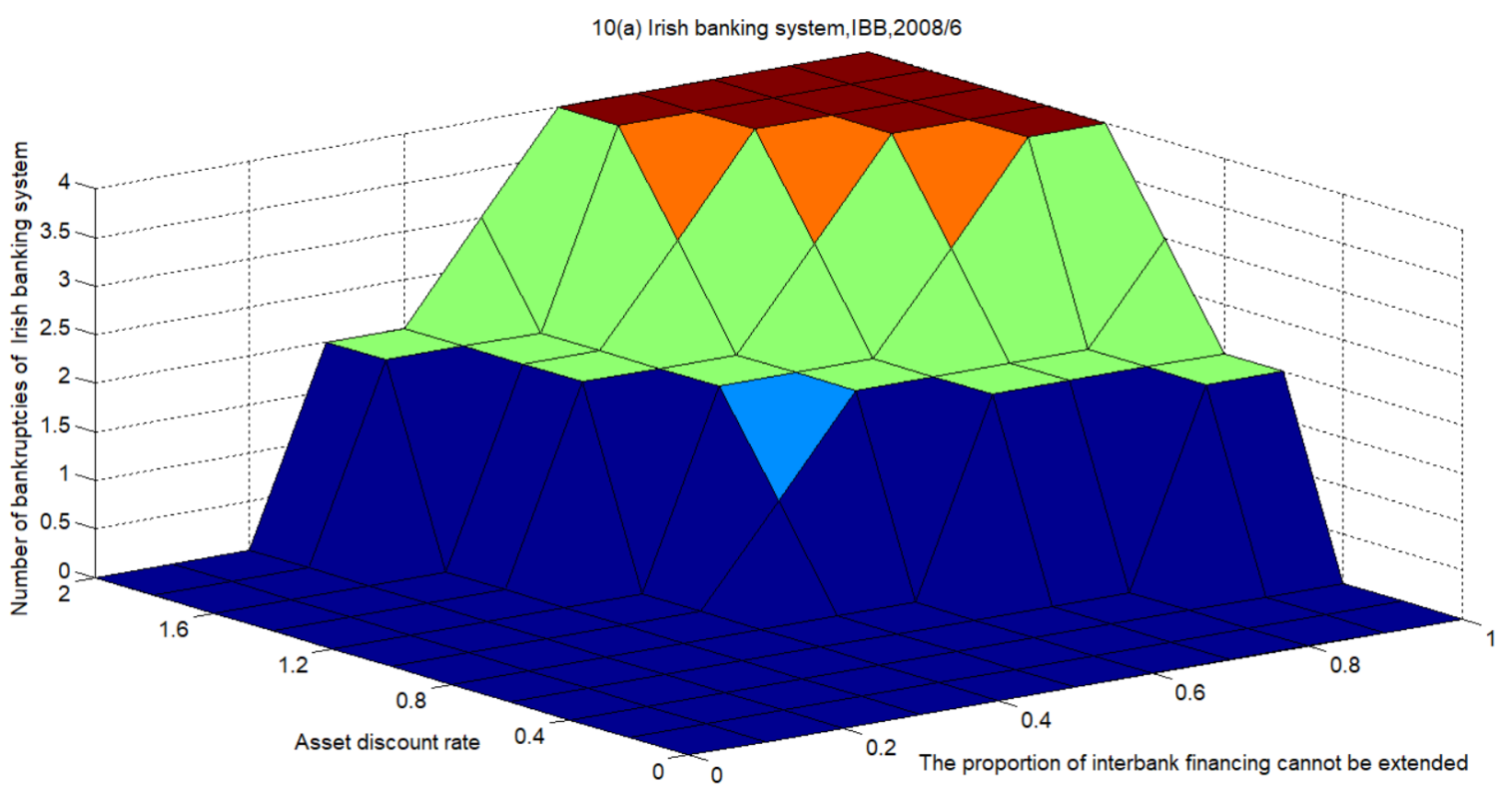

10(b) Greek banking system, IBB,2008/6

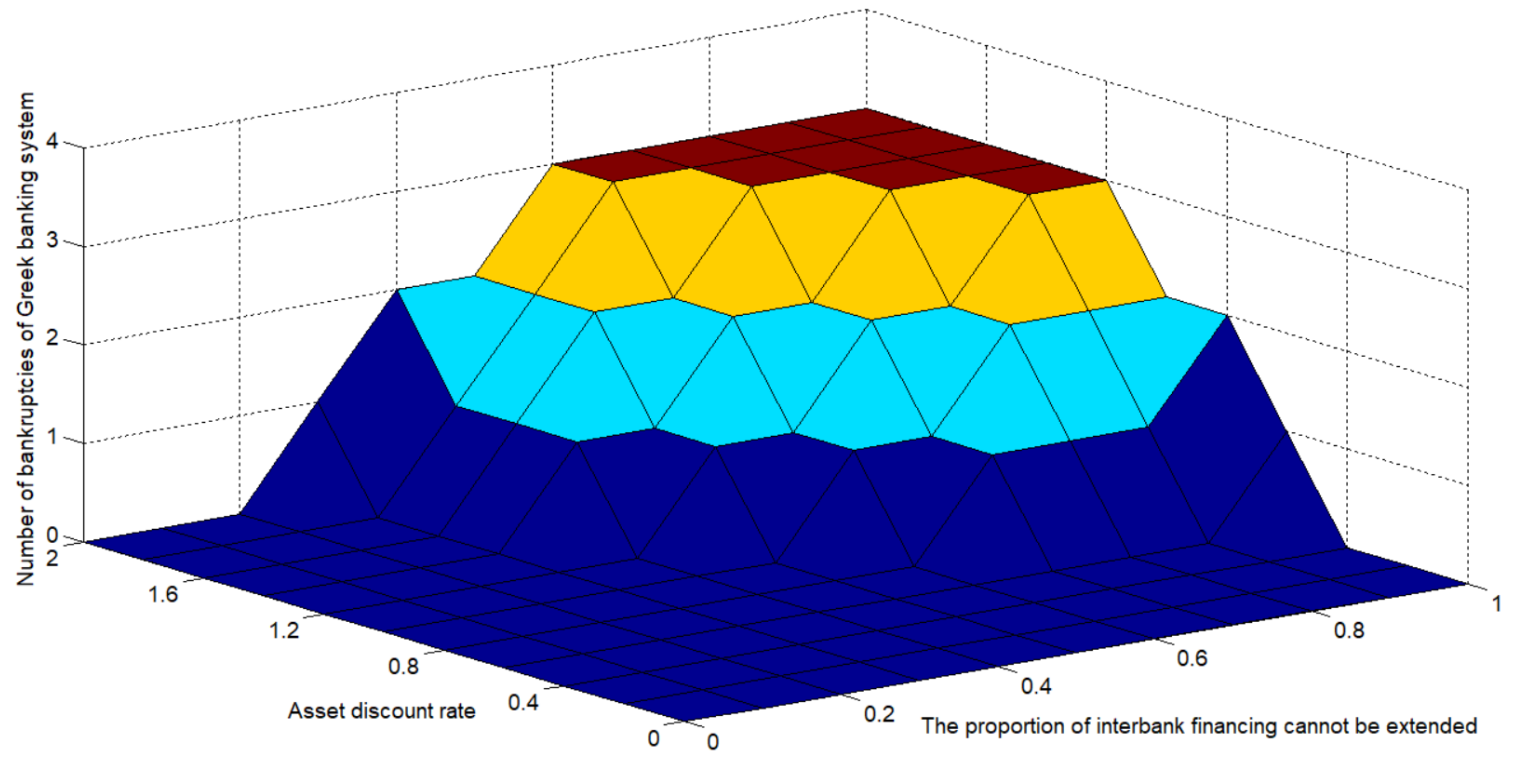


Figure 11: Number of failed banking systems caused by liquidity shock (2007-2017)

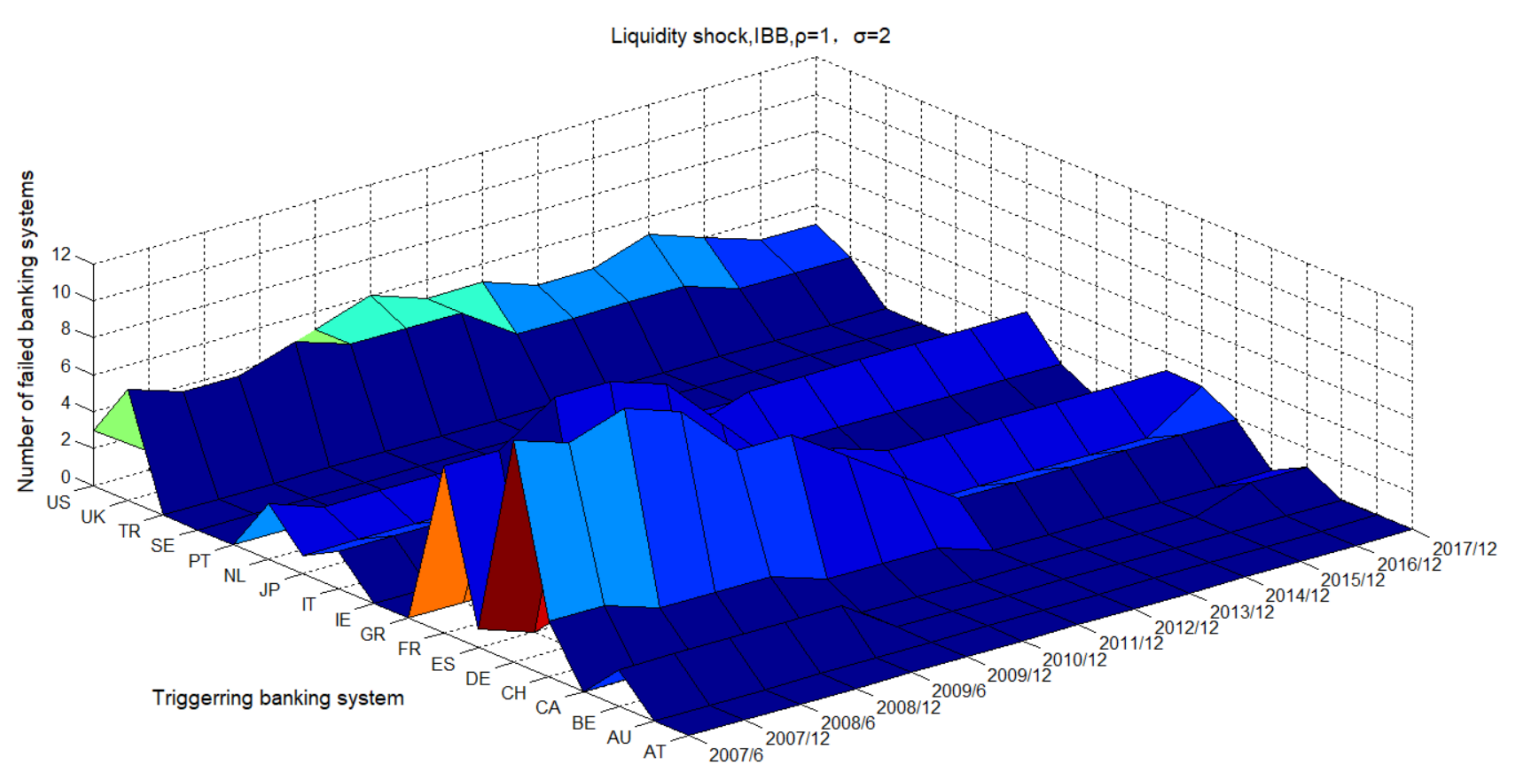

